\title{
EMPLOYEE PSYCHOLOGICAL EMPOWERMENT MODELS AND TEACHING WAYS OF THE
} METHOD

\author{
MODELOS DE EMPODERAMIENTO PSICOLÓGICO DE LOS EMPLEADOS Y FORMAS DE \\ ENSEÑANZA DEL MÉTODO
}

\section{EMPLOYEE PSYCHOLOGICAL EMPOWERMENT MODELS AND TEACHING WAYS OF THE METHOD}

\author{
Ahad Shahbazian ${ }^{1}$ \\ Malikeh Beheshtifar ${ }^{2}$
}

\begin{abstract}
Although individuals have the potential of showing more creativity, innovation, and performance, these capabilities are not exploited optimally in the organizational environment. Psychological empowerment of human resources has been known as an effective strategy in functioning and enhancement of human resources in transition management so educating the method is of great importance. Accordingly, the present study was conducted to analyze employee psychological-empowerment models and the ways of educating that. The paper was theoretical. The concept of empowerment and empowerment models were dealt with based on approaches using library method to realize the purpose of the paper. Then the empowerment models by (Bowen \& Lawler, 1992), (Kanger \& Kanengo, 1988), (Avolio, 2004), (Nokelainen \& Ruhotie, 2003), (Dennis, 1984), (Robbins et al, 2018), (Villegas, 2019), (Vogt \& Murrel, 1990), (Noller, 1997), (Thomas \& Volhaus, 2017), (Spritzer, 1995), Iran Human Resources Empowerment Model, and so on were analyzed. After the analysis of the models, the effective model of employee psychological empowerment was extracted, involving the components of organizational culture, organizational structure, organizational monitoring system, organizational reward system, and the organizational management systems. Some aspects were considered for each component according to the conducted analyses and studying and comparing the models developed in this regard.
\end{abstract}

Keywords: Teaching Psychological empowerment, Transition management, Human resources, Employees.

\footnotetext{
${ }^{1}$ Islamic Azad University. Rafsanjan, Iran.

${ }^{2}$ Islamic Azad University. Rafsanjan, Iran.
} 
Resumen: Aunque las personas tienen el potencial de mostrar más creatividad, innovación y rendimiento, estas capacidades no se explotan de manera óptima en el entorno organizacional. El empoderamiento psicológico de los recursos humanos ha sido conocido como una estrategia efectiva en el funcionamiento y la mejora de los recursos humanos en la gestión de la transición, por lo que educar el método es de gran importancia. En consecuencia, el presente estudio se realizó para analizar los modelos de empoderamiento psicológico de los empleados y las formas de educarlo. El trabajo fue teórico. El concepto de empoderamiento y los modelos de empoderamiento se abordaron en base a enfoques que utilizan el método de la biblioteca para realizar el propósito del documento. Luego, los modelos de empoderamiento de (Bowen y Lawler, 1992), (Kanger y Kanengo, 1988), (Avolio, 2004), (Nokelainen y Ruhotie, 2003), (Dennis, 1984), (Robbins et al, 2018), ( Villegas, 2019), (Vogt y Murrel, 1990), (Noller, 1997), (Thomas y Volhaus, 2017), (Spritzer, 1995), el Modelo de Empoderamiento de Recursos Humanos de Irán, etc., fueron analizados. Después del análisis de los modelos, se extrajo el modelo efectivo de empoderamiento psicológico de los empleados, que involucra los componentes de la cultura organizacional, la estructura organizacional, el sistema de monitoreo organizacional, el sistema de recompensa organizacional y los sistemas de gestión organizacional. Se consideraron algunos aspectos para cada componente de acuerdo con los análisis realizados y el estudio y la comparación de los modelos desarrollados al respecto.

Palabras clave: Enseñanza del empoderamiento psicológico, Gestión de la transición, Recursos humanos, Empleados.

Resumo: Embora os indivíduos tenham o potencial de mostrar mais criatividade, inovação e desempenho, esses recursos não são explorados de maneira ideal no ambiente organizacional. $O$ empoderamento psicológico dos recursos humanos tem sido conhecido como uma estratégia eficaz no funcionamento e aprimoramento dos recursos humanos no gerenciamento de transição, de modo que a educação do método é de grande importância. Nesse sentido, o presente estudo foi realizado para analisar os modelos de capacitação psicológica dos funcionários e as formas de educá-lo. O trabalho foi teórico. O conceito de empoderamento e modelos de empoderamento foi tratado com base em abordagens usando o método da biblioteca para realizar o objetivo do artigo. Em seguida, os modelos de empoderamento de (Bowen \& Lawler, 1992), (Kanger \& Kanengo, 1988), (Avolio, 2004), (Nokelainen \& Ruhotie, 2003), (Dennis, 1984), (Robbins et al, 2018) ( Villegas, 2019), (Vogt \& Murrel, 1990), (Noller, 1997), (Thomas \& Volhaus, 2017), (Spritzer, 1995), Iran Human Resources Empowerment Model, e assim por diante foram analisados. Após a análise dos modelos, foi extraído o modelo efetivo de empoderamento psicológico dos funcionários, envolvendo os componentes da cultura organizacional, estrutura organizacional, sistema de monitoramento organizacional, sistema de recompensa organizacional e sistemas de gestão organizacional. Alguns aspectos foram considerados para cada componente de acordo com as análises realizadas e estudando e comparando os modelos desenvolvidos nesse sentido.

Palavras-chave: Ensino de empoderamento psicológico, Gestão de transição, Recursos humanos, Empregados.

\section{INTRODUCTION}

The most significant and vital asset of any organization is its human resources. Quality and capability of human resources are the most significant elements in the survival of the organization. Capable man force creates a capable organization. To economic growth lies in empowering educated staff. A capable organization is an environment in which the employees in various groups collaborate in accomplishing activities. Employee empowerment is the most key effort of the 
managers in innovation, decentralization, and elimination of bureaucracy in organizations. Empowering people enables the managers and organizations reach their goals faster and without the waste of resources. Empowering makes the employees consider the organization and jobs as their own and be proud of working there. Empowering potential capacities brings about the exploitation of the resources of human capabilities that are not fully utilized (Shahabi \& Emaminejad, 2017). In an empowered organization, the employees are the main driving force behind employees. It is the employees who implement their best innovations and ideas with a sense of excitement, ownership, honor and responsibility. At the same time, the leaders cannot empower their followers unless they are sympathetic, motivated and honest, loyal and realistic (Baghersalimi \& Dashmir, 2018). Accordingly, the present paper was conducted to analyze employee psychological-empowerment models.

\section{METHODOLOGY}

The paper was theoretical and library in terms of methodology. The required information was collected by reviewing books and papers in the research field using a checklist.

\section{Empowerment concept}

Empowerment is widely used in different ways. Many of the managers talk about empowerment in the workplace and the writers and experts recommend empowerment management as the solution to many organizational problems. Empowerment has been used in areas such as social work, urban redevelopment and external development for many years but what is empowerment?

According to empowerment means sharing power and 1) judgment (work value), 2) competence (ability to do the task), 3) independence (choice of action and initiative), and 4) impact

(the ability to affect organizational outcomes). (Samadi Mirklaei et al, 2013) argued that empowerment is guiding the decision-making process in the lower ranks of the organization. (Lotfi Zanganeh et al, 2014) have defined empowerment as transferring responsibility to those closest to the problem. They believed that work, vote independence, power, commitment, and culture affect empowerment. 
In a seminal study, (Thomas \& Volhaus, 2017) have identified four aspects of psychological empowerment in a conceptual model. These four aspects include 1) feeling effective, 2) feeling having a right to choose, 3) feeling competent and 4) feeling meaningful. The meaning of feeling effective is whether doing a particular job or task that can make a difference in the overall job. The more employees believe in this impact, the more motivation they feel. The feeling of having the right to choose is determining a specific behavior by oneself. According to this model, the more people feel empowered, the more they have the opportunity to choose their tasks, how they do their job and assume responsibility for the results of their job. The third factor is feeling competence. The people must have skills, knowledge, experience, and other required abilities to move forward to reach empowerment. Ultimately, feeling meaningfulness of the work, which is very important, shows the value of the job or duty in relation to specific opinions, ideas, and standards. The more the task is consistent with one's value system, the more belief in doing the job is created. Without the sense of meaningfulness, there is no probability to reach empowerment (Ghiasi Nadoushan et al, 2016).

\section{METHOD}

\section{Empowerment models based on approaches}

Studying human resource management literature indicates various approaches for empowering employees. Each modeling authority has their own definition of empowerment, its process, and the elements and factors affecting it as presented in their model. Indeed, it shows an approach in this field that by summing up their models, they can be grouped together and named as one approach (Table 1).

Table 1- Empowerment models according to the approaches

\begin{tabular}{llll}
\hline Row & $\begin{array}{l}\text { The type of Empowerment topic } \\
\text { approach }\end{array}$ & Model presenter \\
\hline $\mathbf{1}$ & $\begin{array}{l}\text { Mechanical / } \\
\text { rational } \\
\text { structural } \\
\text { approach }\end{array}$ & Delegation of power and & $\begin{array}{l}\text { Scott \& Jaffe, Bowen \& Lawler, } \\
\text { Shovel, Foy, Veget, Blanchard et al., } \\
\text { Bork, Coen, Dotic, Mills \& angels, } \\
\text { Destranj }\end{array}$ \\
$\mathbf{2}$ & $\begin{array}{l}\text { Motivational } \\
\text { approach }\end{array}$ & $\begin{array}{l}\text { Staff autonomy and self- } \\
\text { sufficiency }\end{array}$ & \multicolumn{1}{l}{ Kanger, Kanger and Kanengo } \\
\hline
\end{tabular}




\begin{tabular}{|c|c|c|c|}
\hline 3 & $\begin{array}{l}\text { Psychological } \\
\text { approach }\end{array}$ & Internal motivation & $\begin{array}{l}\text { Thomas and Voltheus, Spritzer, } \\
\text { Aulio }\end{array}$ \\
\hline 4 & $\begin{array}{l}\text { Interactive } \\
\text { approach }\end{array}$ & $\begin{array}{l}\text { Communication and team } \\
\text { building skills }\end{array}$ & Harley \\
\hline 5 & $\begin{array}{l}\text { Cognitive } \\
\text { approach }\end{array}$ & $\begin{array}{l}\text { Increasing knowledge and } \\
\text { skills }\end{array}$ & $\begin{array}{l}\text { Fisher, Deft, Jeroy, Wright and } \\
\text { Anderson }\end{array}$ \\
\hline 6 & $\begin{array}{l}\text { Cultural-value } \\
\text { approach }\end{array}$ & $\begin{array}{l}\text { Strengthen beliefs, ethics } \\
\text { and commitment }\end{array}$ & $\begin{array}{l}\text { Blancharo \& Zigarmy, Kinella, } \\
\text { Gordon, Quinn \& Spritzer, Saury \& } \\
\text { Locke }\end{array}$ \\
\hline 7 & $\begin{array}{l}\text { Integrated } \\
\text { approach }\end{array}$ & $\begin{array}{l}\begin{array}{l}\text { Environmental factors, } \\
\text { individual elements, } \\
\text { managerial strategies }\end{array}\end{array}$ & Robins, Craneau and Ferdinand \\
\hline
\end{tabular}

Bowen \& Lawler Empowerment Model (1992)

According to (Bowen \& Lawler, 1992), organizational empowerment factors include the following four components:

- Information on the organization performance

- Rewards based on organizational performance

- The power in making decisions based on organization orientation

- Power in decisions based on the organizational performance

(Bowen \& Lawler, 1992) believed that empowerment exists when the companies distribute power, knowledge, information, and rewards across the organization. In this model, the relationship between four elements of empowerment is as mathematical multiplication, which means if one of the four elements is zero, empowerment would be zero, as well and there would be the lack of empowerment (Ghorbanizadeh \& Aghavardi, 2013) (Figure 1). 


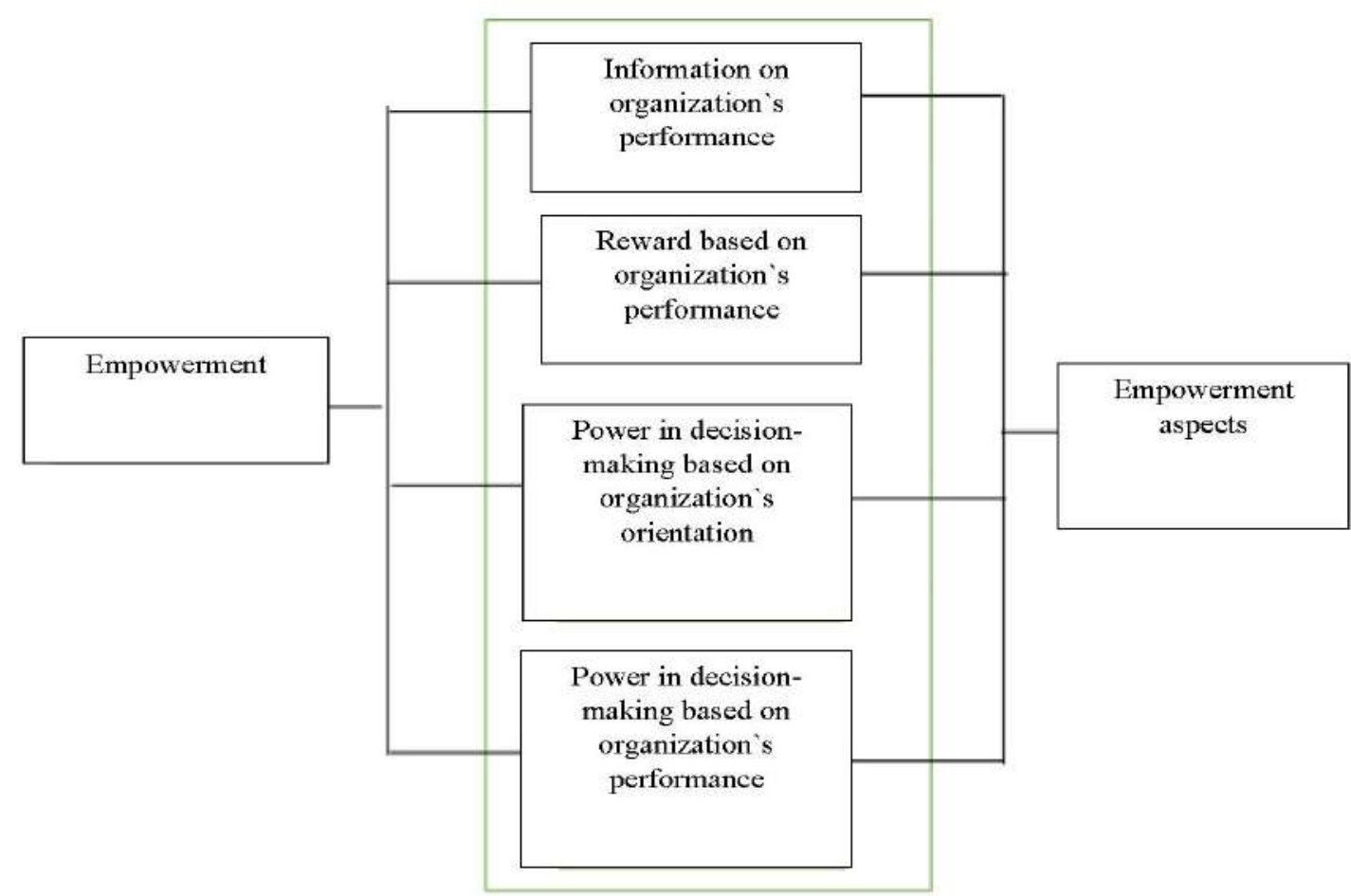

Figure 1- Employee Empowerment Model of

Kanger \& Kanengo Empowerment Model (1988)

(Kanger \& Kanengo, 1988) argued that structural empowerment is a process and stimulus that is delegated to individuals, and involves creating conditions for increased motivation to perform enhancing the sense of self-efficacy among organizational members as well as situational recognition. They stated that the need for empowerment increases when the staff feels disabled. Thus, it is critical to examine the internal conditions of organizations where employees feel disabled, one of which is identifying empowerment strategies and techniques, however, changing environmental conditions is not always possible. Thus, strategies should be used to increase the information effectiveness of employees to change the level of staff empowerment. Given the above, a five-step process can be presented that includes the empowerment process according to the behavioral conditions and outcomes; these five steps are presented in (Figure 2). 

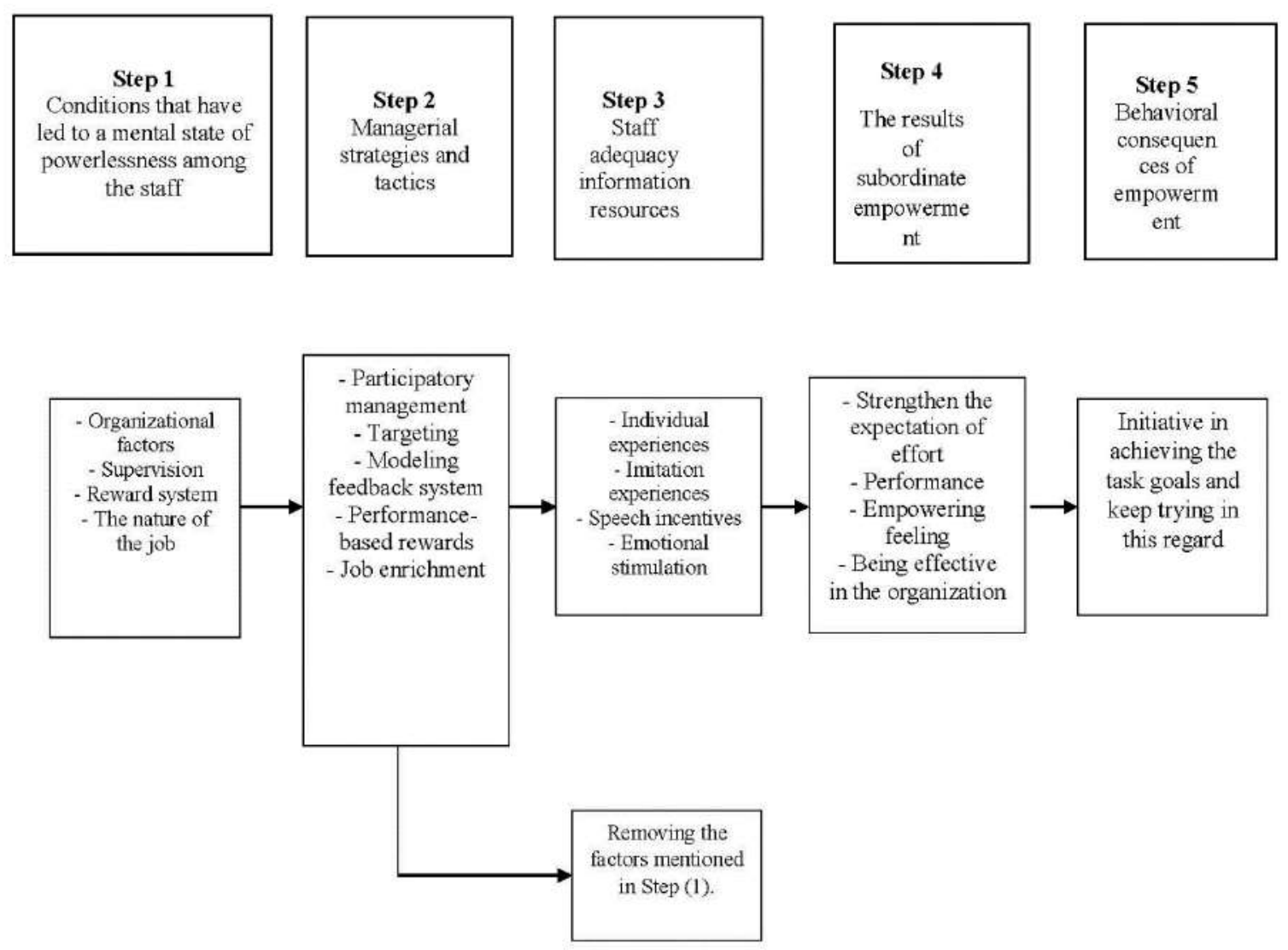

Figure 2- The five stages of the motivational process of empowerment by

\section{Avolio empowerment model (2004)}

(Avolio, 2004) defined psychological empowerment as empowering the intrinsic motivation in a set, the four knowledge comprising empowerment, affect, meaning, and autonomy in reflecting the individual's direction relative to the role of the individual in the work. According to (Avolio, 2004), empowerment means feeling empowered and able to do the job successfully, affecting the effectiveness of one's activity in pursuing organizational goals, meaningful weighting that individuals consider a standard to work for, and autonomy means a sense of independence. It is decision making (Kordnaij et al, 2015) (Figure 3). 


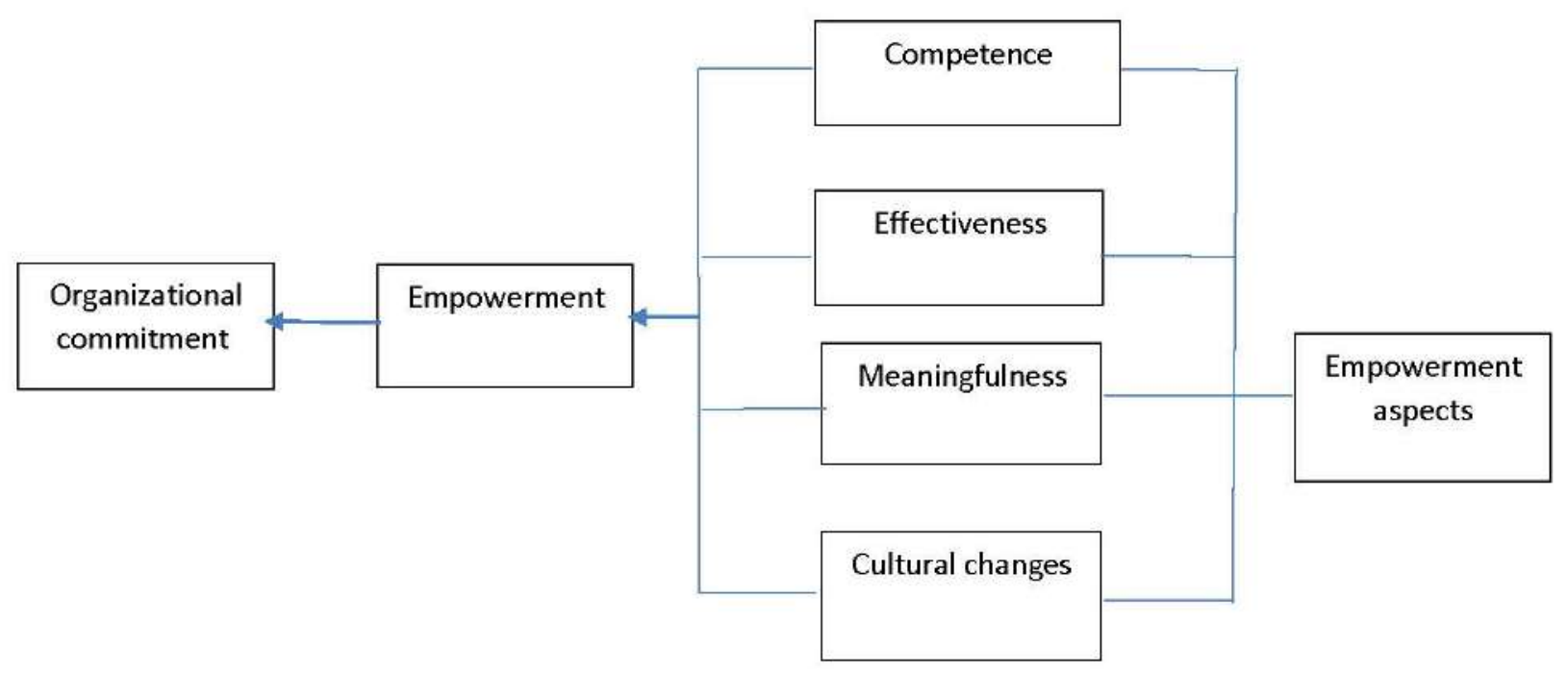

Figure 3- Avolio's Employee Empowerment Model

The Empowerment Model of Nokelainen \& Ruhotie (2003)

According to (Nokelainen \& Ruhotie, 2003), the operational capacity of the group is the ability to work and learn by collaboration, and the increase in the stress destroys the atmosphere of organizational growth (empowerment). (Nokelainen \& Ruhotie, 2003) have dealt with empowerment using a partial approach, considering it as the creation of meaningful, interrelated relationships based of which individual motivation in employees is developed besides the distribution of power and control in the organization. According to these two scholars, structural empowerment is a motivational construct that emphasizes on the people's cognition and emotion. The two most relate empowerment development to personal impact concepts and output outcomes, and perceive empowerment as a developmental approach. Most employees have defined power (Figure 4).

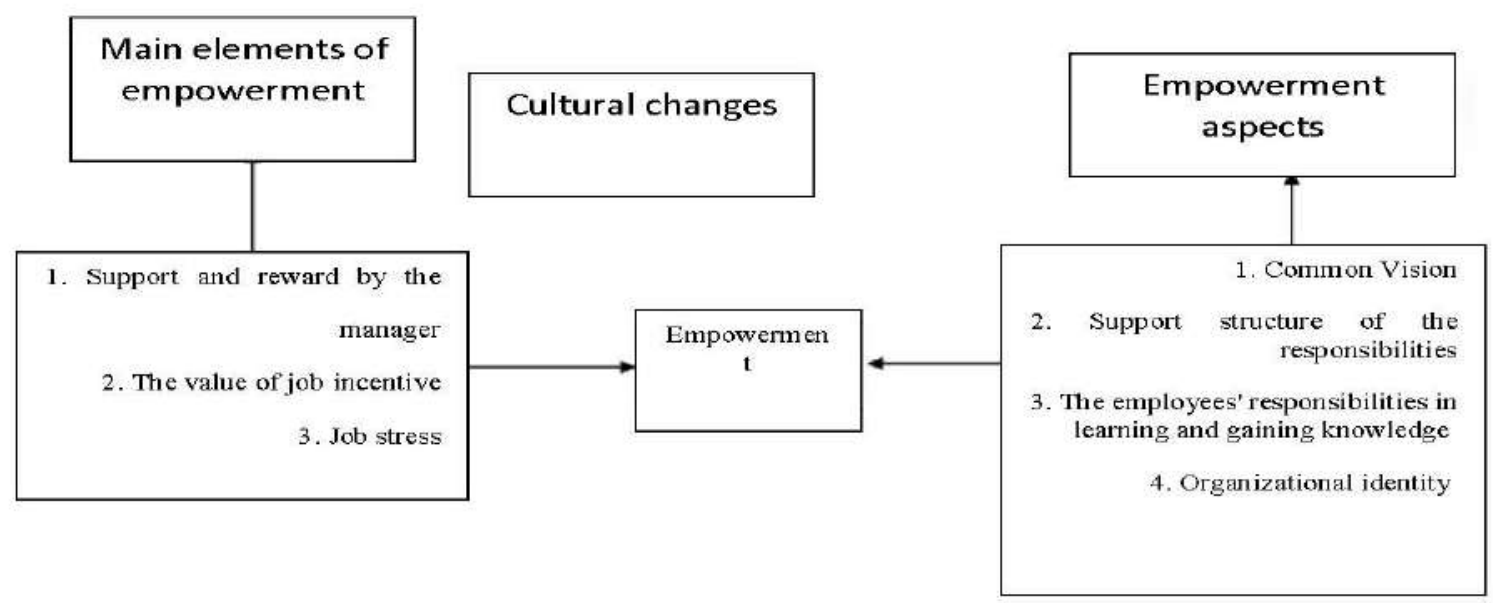

Figure 4- Nokelainen \& Ruhotie Employee Empowerment Model 


\section{Geroy, Wright \& Anderson Employee Empowerment Model (1998)}

According to these three scholars, empowerment is one of the most significant concepts of modern management theory. Empowerment is the process of guiding and developing the skills necessary for employees to make independent decisions within the organizational culture and process. Empowerment is a structure that can break traditions. In empowers organizations hence makes the employees have more solutions to their problems. Empowerment in these organizations is the act of trusting each other in exchanging views and respect to each other. Empowerment in its true sense is the knowledge used in special, necessary, and distressing situations. In their conventional model of strategic performance empowerment, they have outlined the three key indices of empowerment potential. These three indices are:

- Guidance

- Behavior model

- Developing employee policy

According to them, guidance is an informal process for creating the right behaviors for employees by enhancing their ability and skill level. Guidance is a process that stresses what people do right and the ways they can do better. Behavioral model is one of the most effective forms of developing employees' skills and development and changing behaviors. A good guidance has to select the right model for the attention of the employees and the managers need to change their guidance to get the results they wish. Managers have trouble creating new management policies therefore they need help (Babolan, 2017) (Figure 5).

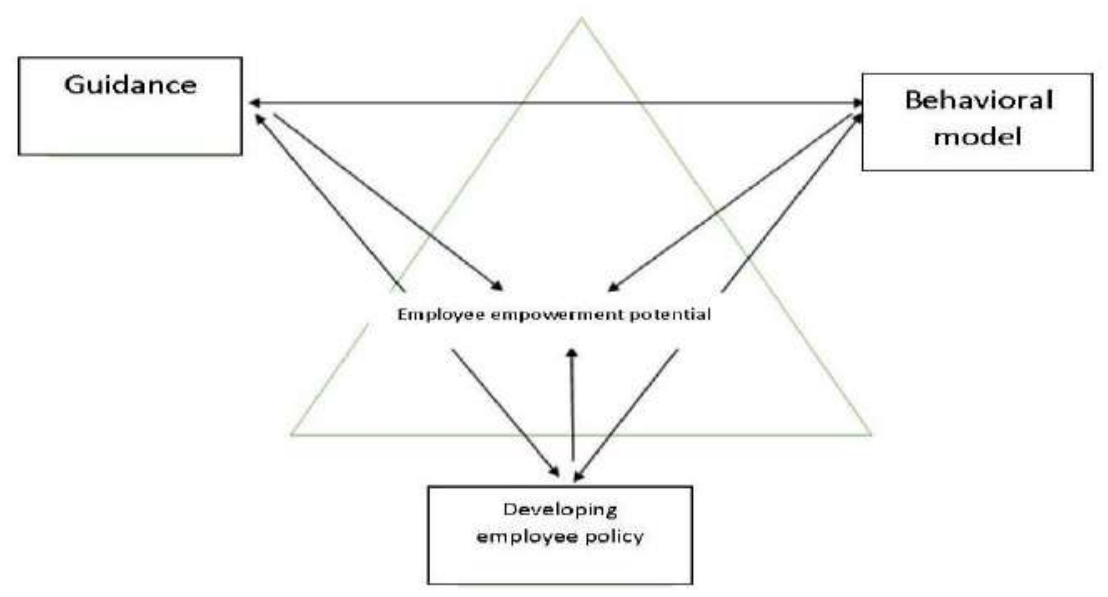

Figure 5- Geroy, Wright \& Anderson Empowerment Model 


\section{DISCUSSION}

\section{Dennis Kinlaw Employee Empowerment Model (1984)}

According to (Dennis, 1984), empowerment is the process of continuous improvement in organizational performance created by developing and expanding the impact of competent individuals and teams, which in turn affects the performance of individuals and organizations, as well. In this model, six basic steps are designed to create an empowered organization. These steps are completely related and create a cycle. The elements of this cycle are defining and communicating, setting goals and strategies, training, adjusting organizational structure, adjusting organizational systems, evaluation and development.

Kinlaw believed that as part of the step-by-step implementation of the empowerment process, it is imperative that management and staff are aware of a set of information inputs and are fully aware of them. In other words, these six steps can be accomplished once a complete understanding of the knowledge and information mentioned in this cycle is established. These inputs are the meaning of empowerment, impacts and changes, empowerment goals, empowerment strategies, and empowerment control, and roles and functions. Moreover, Kinlaw argued that done empowerment doesn't not reach fruition unless quality elements are created in the employees. These qualitative elements are ethics, commitment, and ability (Shahabi \& Emaminejad, 2017) (Figure 6).

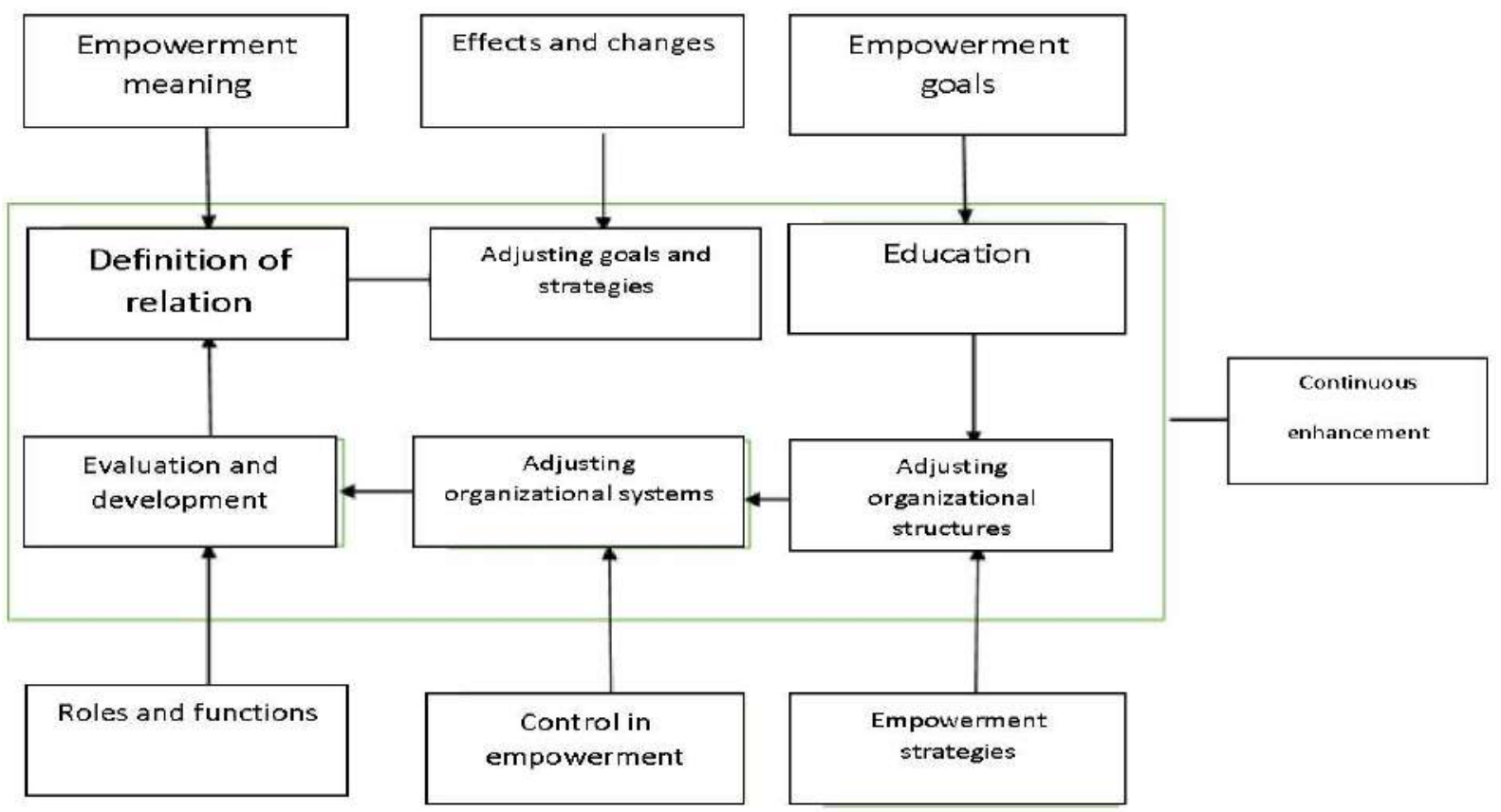

Figure 6- Kinlaw Employee Empowerment Model 
Robbins, Crino \& Fredendal Employee Empowerment Model (2002)

According to these scholars, although empowerment has been defined as instinctive incentives or reaction to an instinctive stimulus in many studies, empowerment is the adoption of a specific plan, adoption of the job`s new structure, power transfer, authority delegation, and participation in information and resources. These three scholars argued that by focusing on environmental factors and individual elements, the best empowerment process can be attained. The most basic step in this process is creating a job environment with a broad organizational context to create an opportunity to benefit from all areas and aspects of empowerment and to provide the motivation required to develop it (Robbins et al, 2018) (Figure 7).

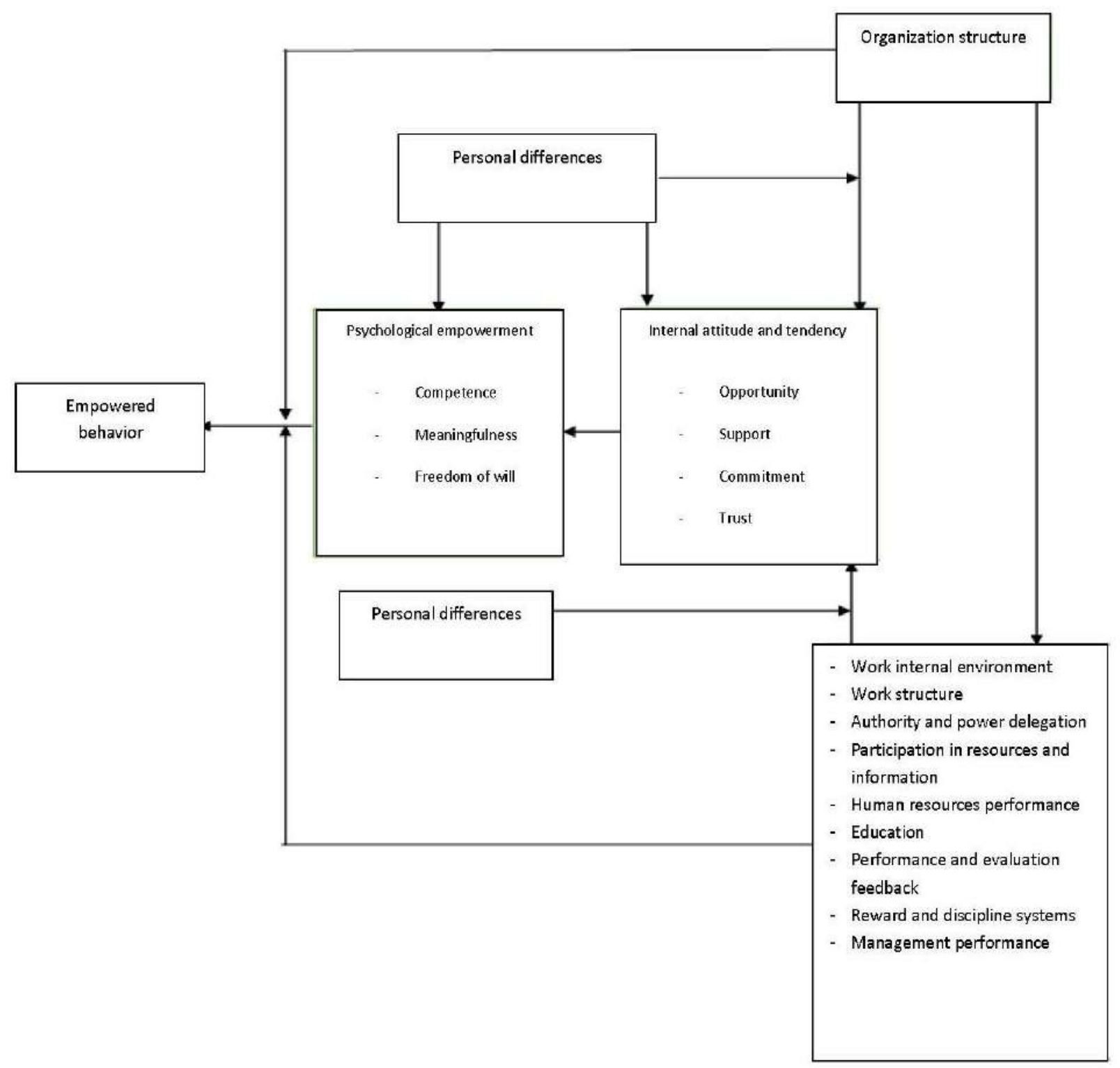

Figure 7- Robbins, Crino \& Fredendal Employees Empowerment Model 
Mc Lagan \& Nel Employee Empowerment Model (1997)

Mc Lagan \& Nel (1997) have proposed a multidimensional approach on employee empowerment. According to them, empowered people delegate their powers and responsibilities to other levels of the organization that directly coordinate with partners to solve the problem (Jazani \& Rostami, 2011) (Figure 8).

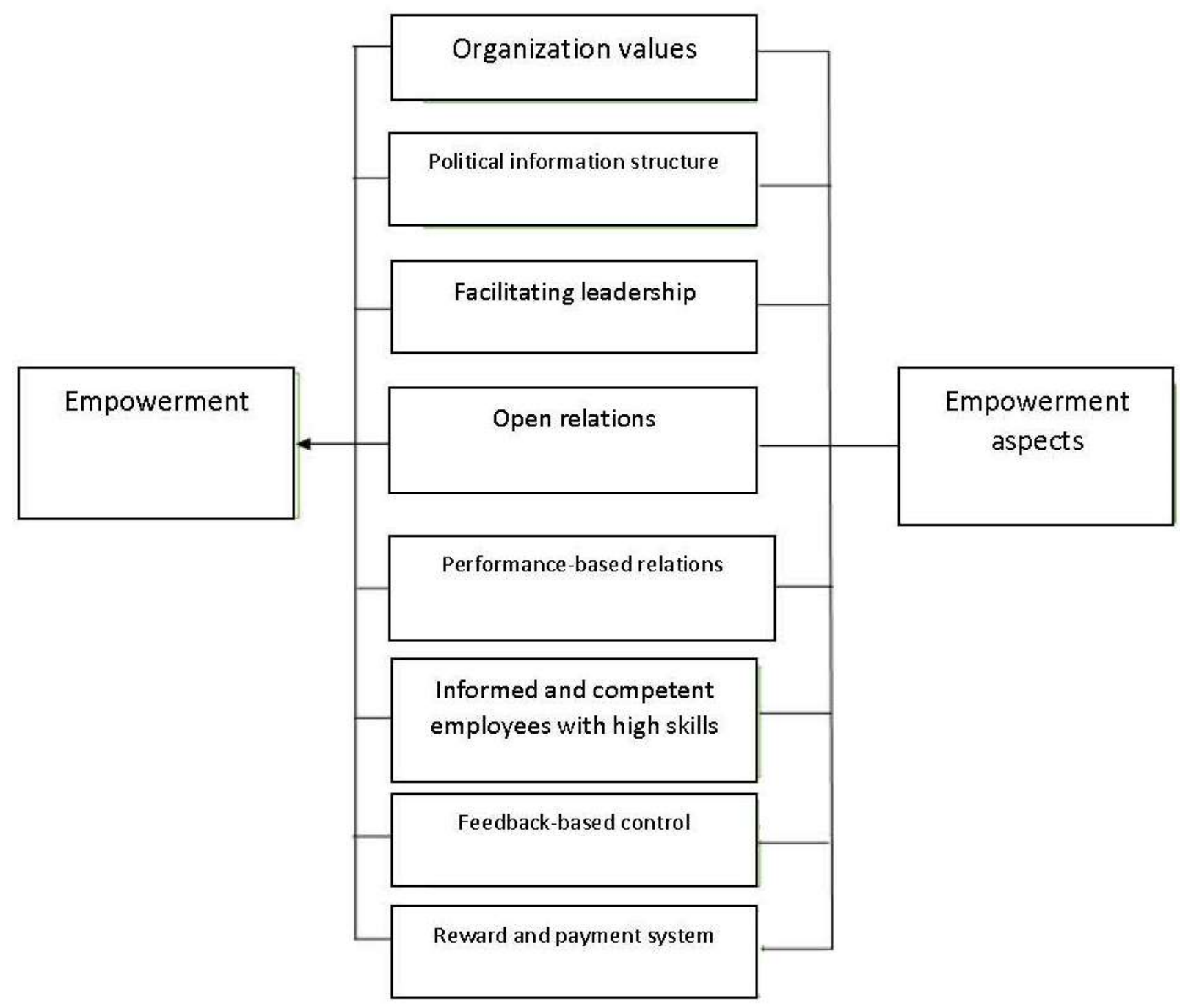

Figure 8- Mc Lagan \& Nel’s Employee Empowerment Model

\section{GAO Institute Employee Empowerment Model (2001)}

GAO Institute conducted a study entitled "Human capital: the measures that lead to staff empowerment" on behalf of the US Senate Committee on Governmental Affairs. The institute targeted five major American organizations or agencies and analyzed all of these agencies' efforts to empower them. The institute proposed the results of its studies in the following steps for staff 
empowerment and believed in focusing on staff empowerment and engaging them in doing the job (Firouzfar et al, 2017) (Figure 9).

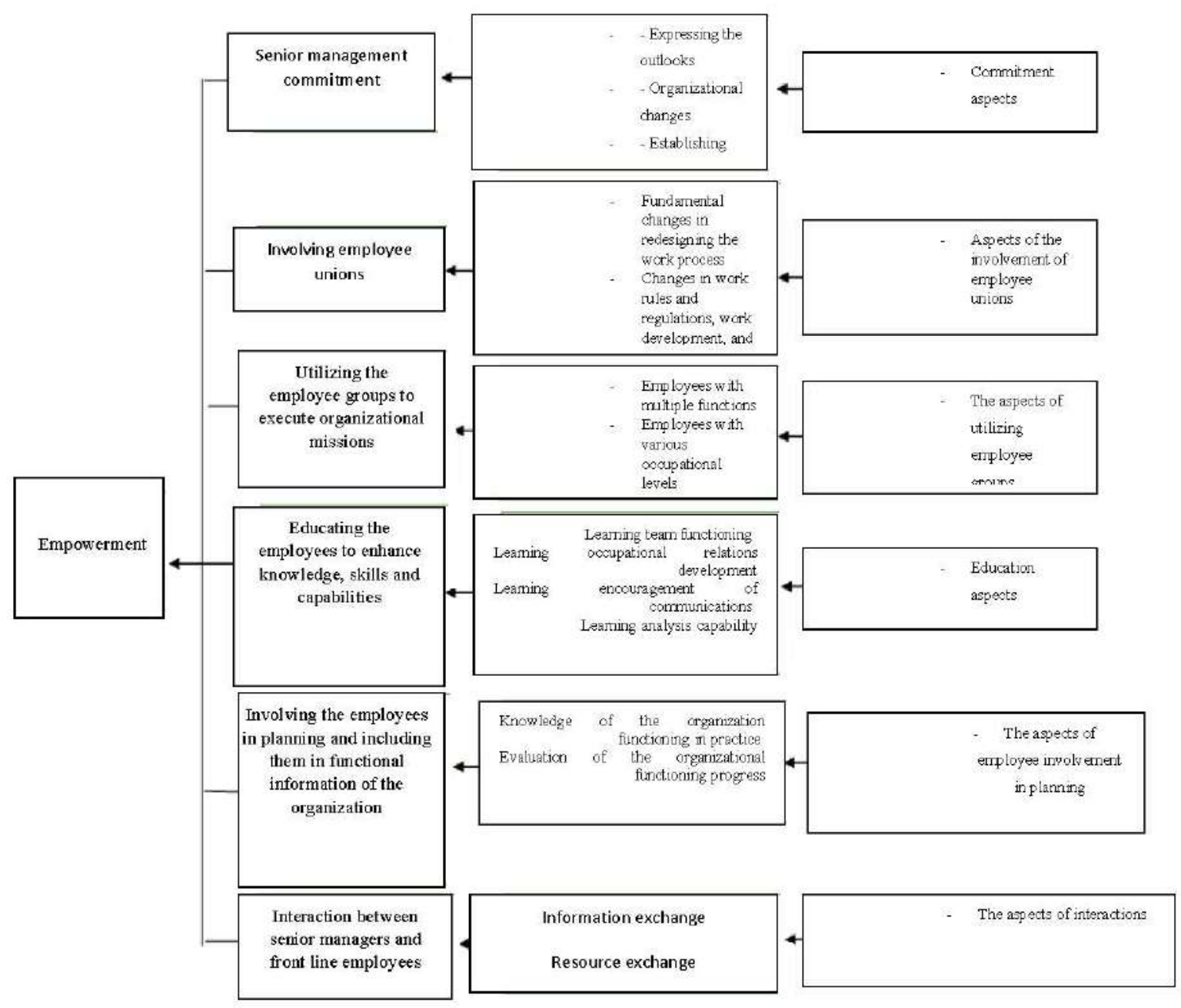

Figure 9- GAO Employee Empowerment Model

Melhem Employee Empowerment Model (2004)

Melhem Employee Empowerment Model is shown in (Figure 10). 


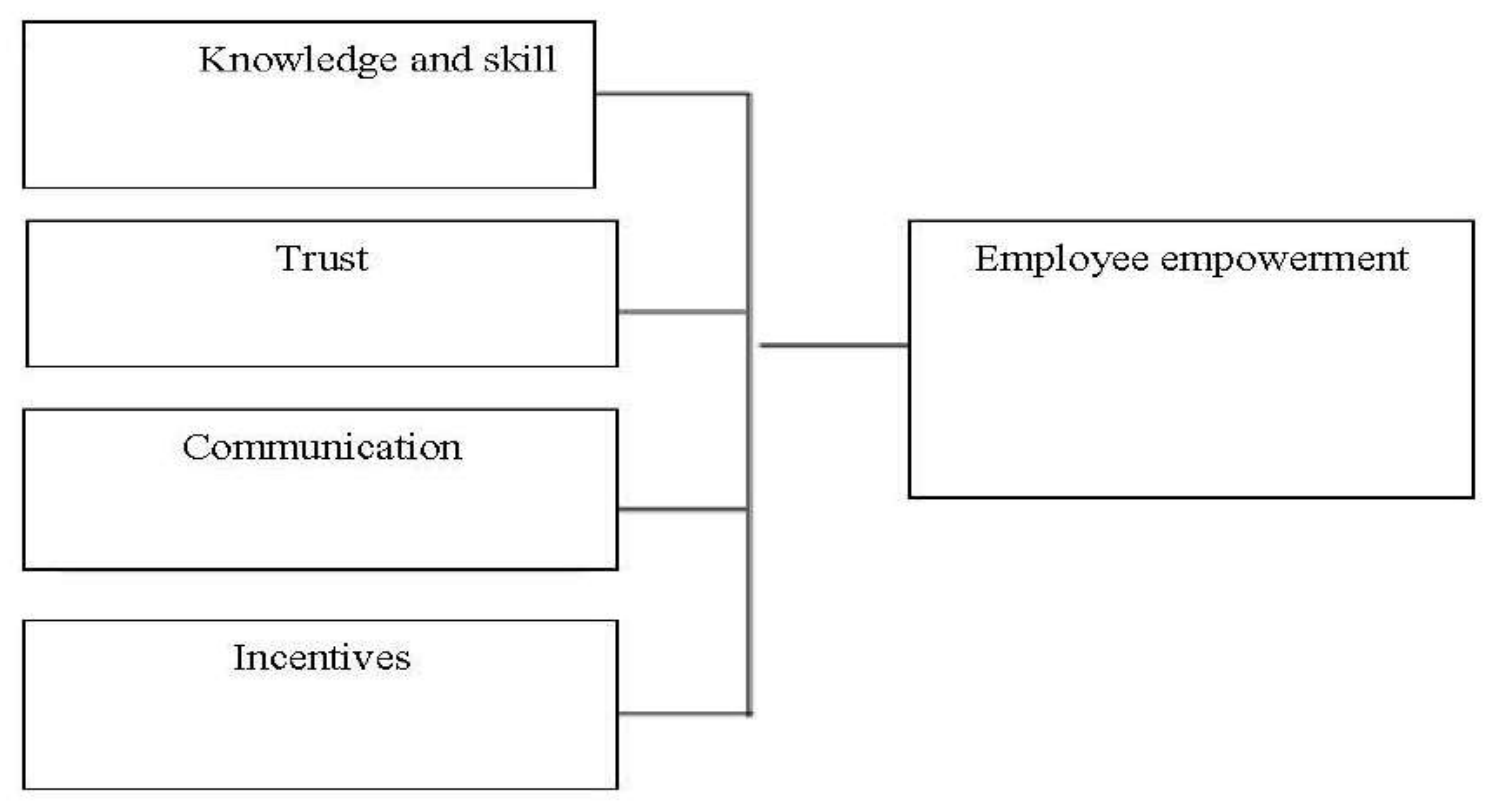

Figure 10. Employee Empowerment Model

Villegas Employee Empowerment Model (2015)

(Villegas, 2019) Employee Empowerment Model is shown in (Figure 11).

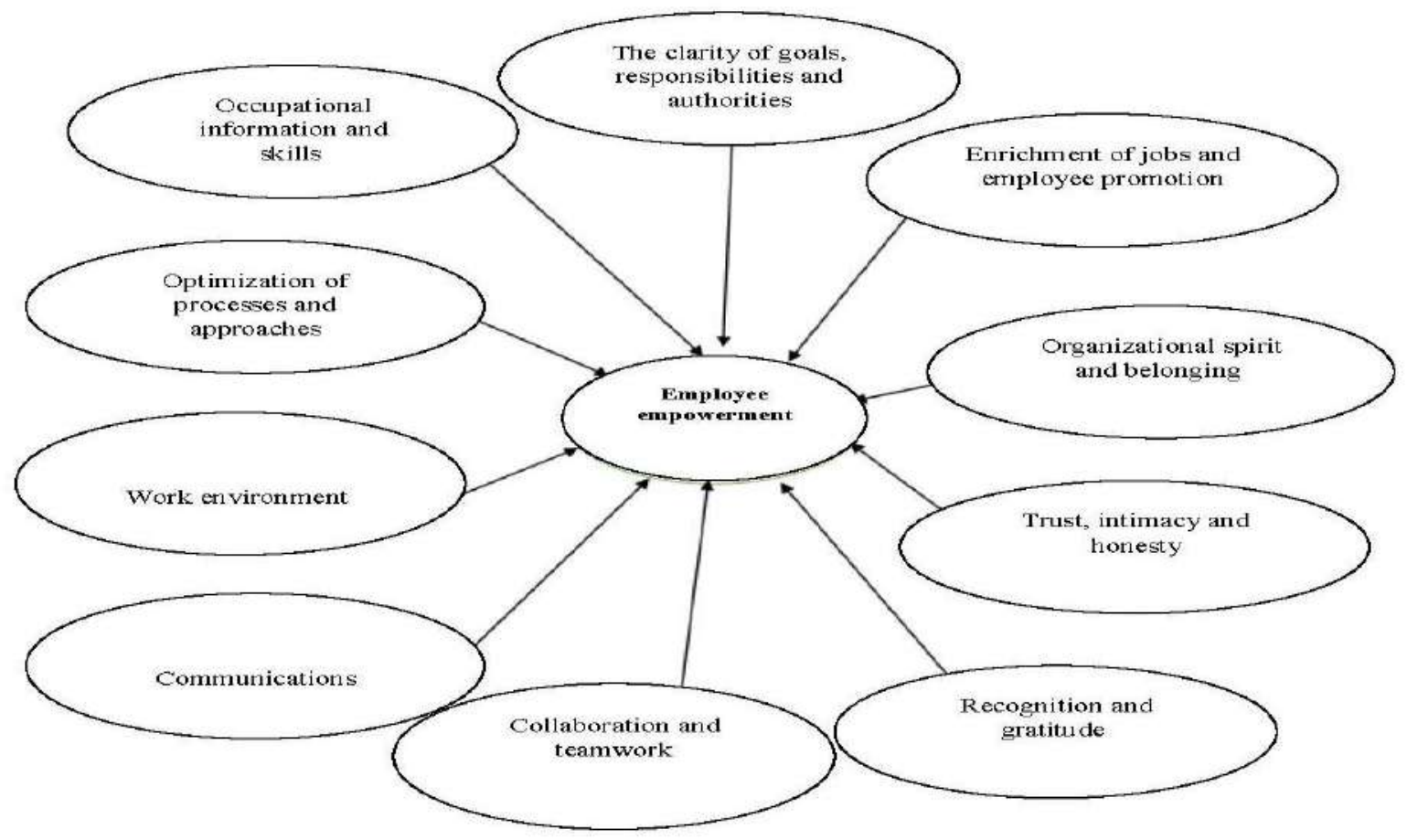

Figure 11- Employee Empowerment Model 


\section{Fox Employee Empowerment Model (1998)}

The empowerment model shows a set of processes and data interactions that interact and lead to continuous improvement. These steps of the empowerment process sequence express and incorporate the information and knowledge needed to manage the process. The empowerment process management model identifies six essential steps that must be followed in planning, implementing, and evaluating an organization's initiative to develop and empower employees. These steps create a closed loop process whose result is continuous improvement.

The six steps of the empowerment process include:

1. Defining and communicating the concept of empowerment to organization members

2. Setting goals and formulating strategies that become an organizational framework for employees at every organizational level in their efforts to develop and enhance empowerment.

3. Training the employees to assume new roles and do their duties in line with the organization goals of expanding and enhancing empowerment.

4. Adapting the organization structure to need lean management, reduced bureaucracy, as well as greater independence and freedom of action.

5. Implementation of organization systems (such as planning, reward, promotion, training, recruitment and so on)

6. Evaluating and refining empowering employees by measuring the improvement and recognition of organization members (Mirmohammadi et al, 2017) (Figure 12). 


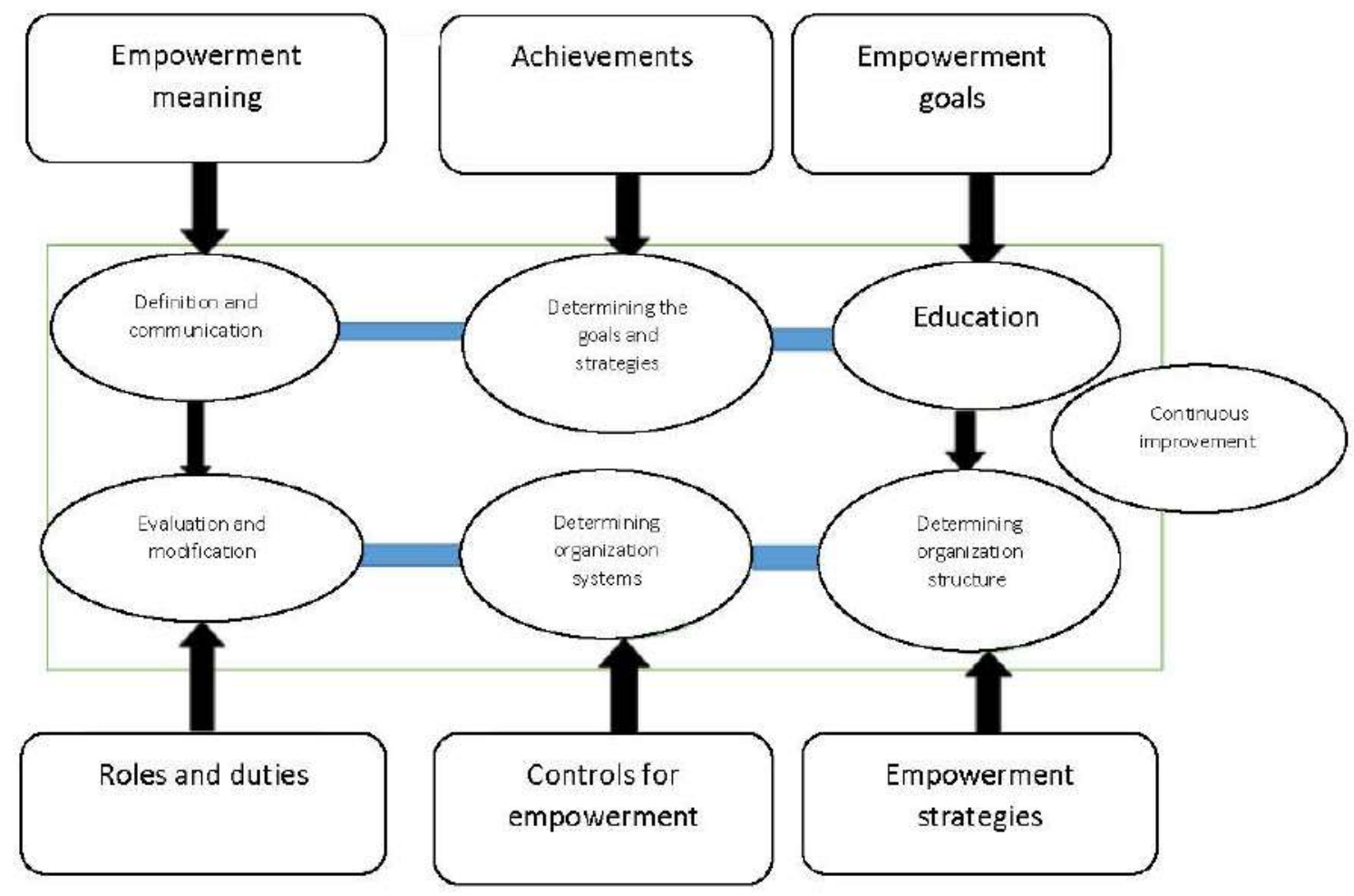

Figure 12- Model of Employee Empowerment Process

\section{Mallak \& Kurstedt Employee Empowerment Model (1996)}

Mallak \& Kurstedt (1996) have considered empowerment as a broader concept of participatory management. They consider empowerment to have four aspects by emphasizing on culturing and the role of managers in employee empowerment. They consider empowerment as a behavior aroused internally leading to internal justification for the work being done. Accordingly, managers delegate their employees in problem solving and give them the responsibility for those tasks. They argued that empowerment must be integrated into the culture of an organization permanently and consistently. This means that one firstly uses another's guidance and models his behavior, then develops his perception of empowerment, develops it and acts accordingly and becomes a leader for others. Moreover, it is the duty of the management to understand that this is a gradual process and should help individuals move through these four stages (Ghiasi Nadoushan et al, 2016) (Figure 13). 


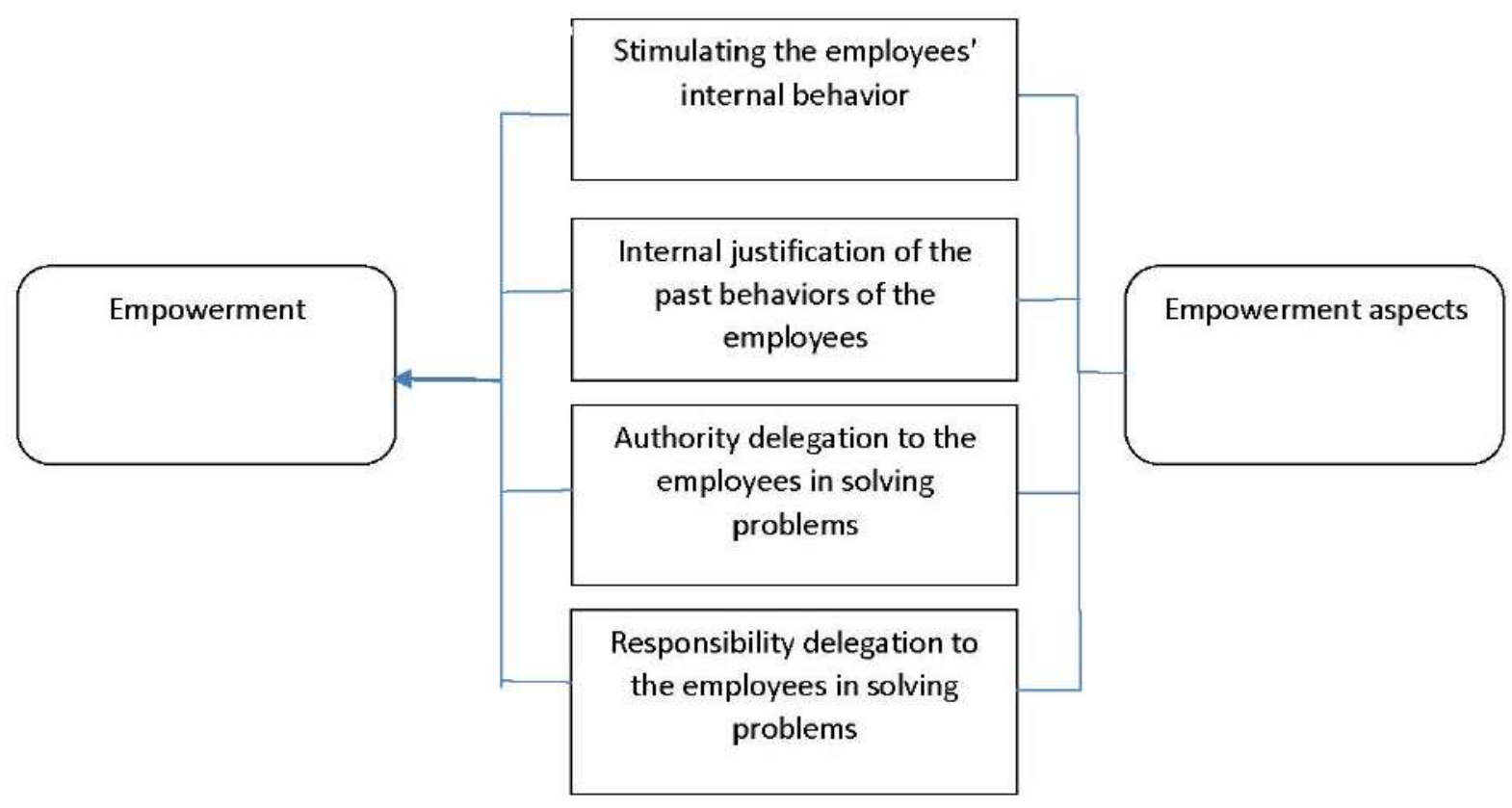

Figure 13- Mallak \& Kurstedt Model of Employees Empowerment Process

\section{Vogt \& Murrel Employee Empowerment Model (1990)}

According to (Vogt \& Murrel, 1990), empowerment is the process of giving individuals the opportunity to make independent organizational decisions. (Vogt \& Murrel, 1990) examined six aspects of empowerment in their proposed empowerment model, including training, leadership, guidance and support, providing facilities, structuring and managing. They believed that those who can integrate all these can start empowering themselves or others. In an empowered organization, employees participate fully as the family, and assume responsibility in taking actions. As they act individually, they work on teams and have the authority to make strategic decisions. This approach stated that the management has to create a culture of participation through the provision of a mandatory, structured mission that emphasizes independence and flexibility, a reward system for participation, permanent participation programs and support for the integration of work and family life (Figure 14). 


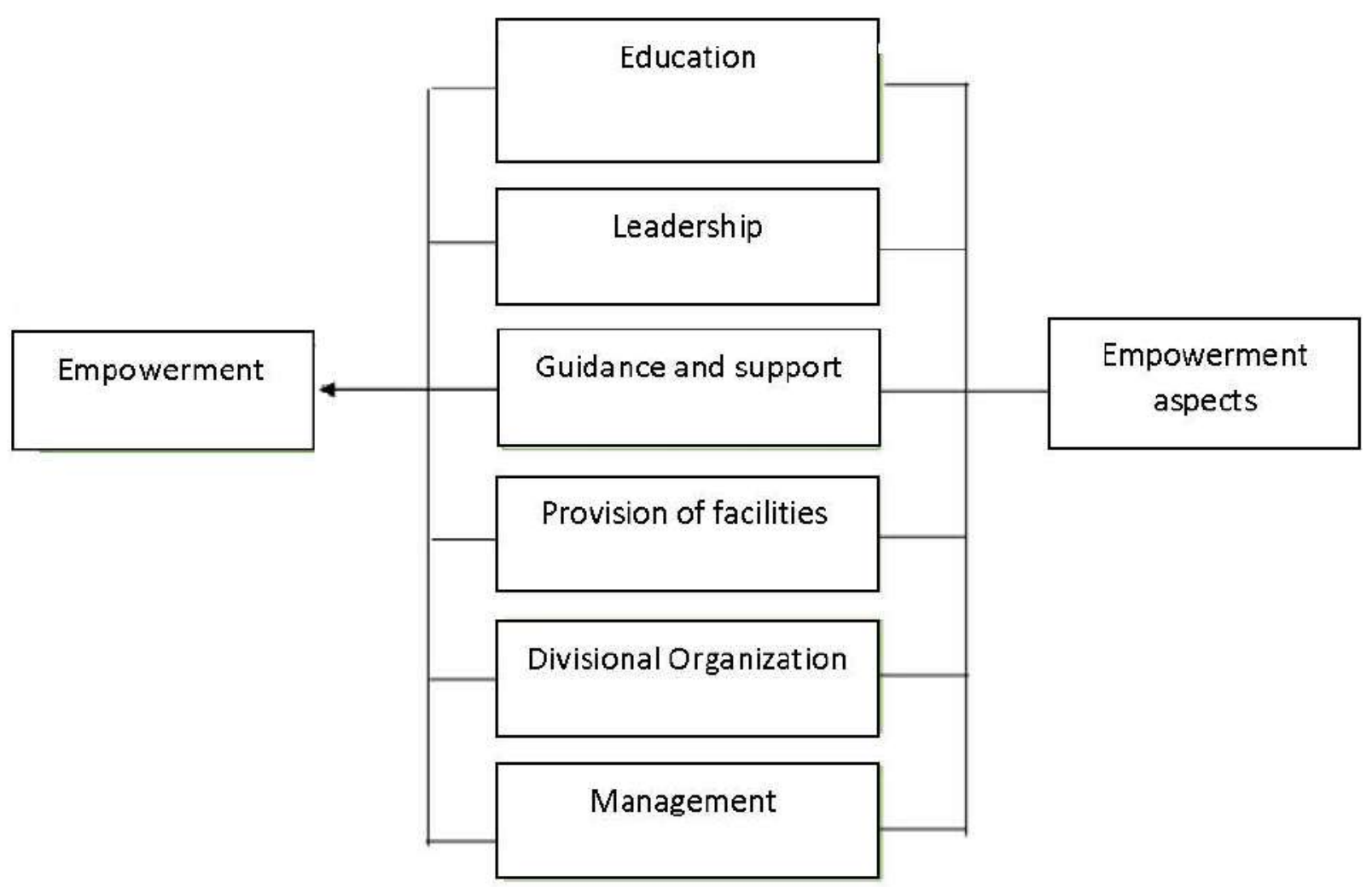

Figure 14- Employee Empowerment Process Model of

Noller Employee Empowerment Model (1997)

(Noller, 1997) has proposed a four-dimensional model of employee empowerment called Weberian ideal model. He stated that we talk of the empowerment of a person or a group of people in a given situation with the following conditions:

- Full decision-making ability

- Accepting full responsibility for the execution of any decision

- Full access to tools related to decision making and its implementation

- Assuming full responsibility for accepting the consequences of any decisions made

(Noller, 1997) argued that this empowerment model is an ideal state in the organization not continually observed and that its vital component is in emphasizing the willingness to accept responsibility for the consequences of taken action and made decisions (Figure 15). 


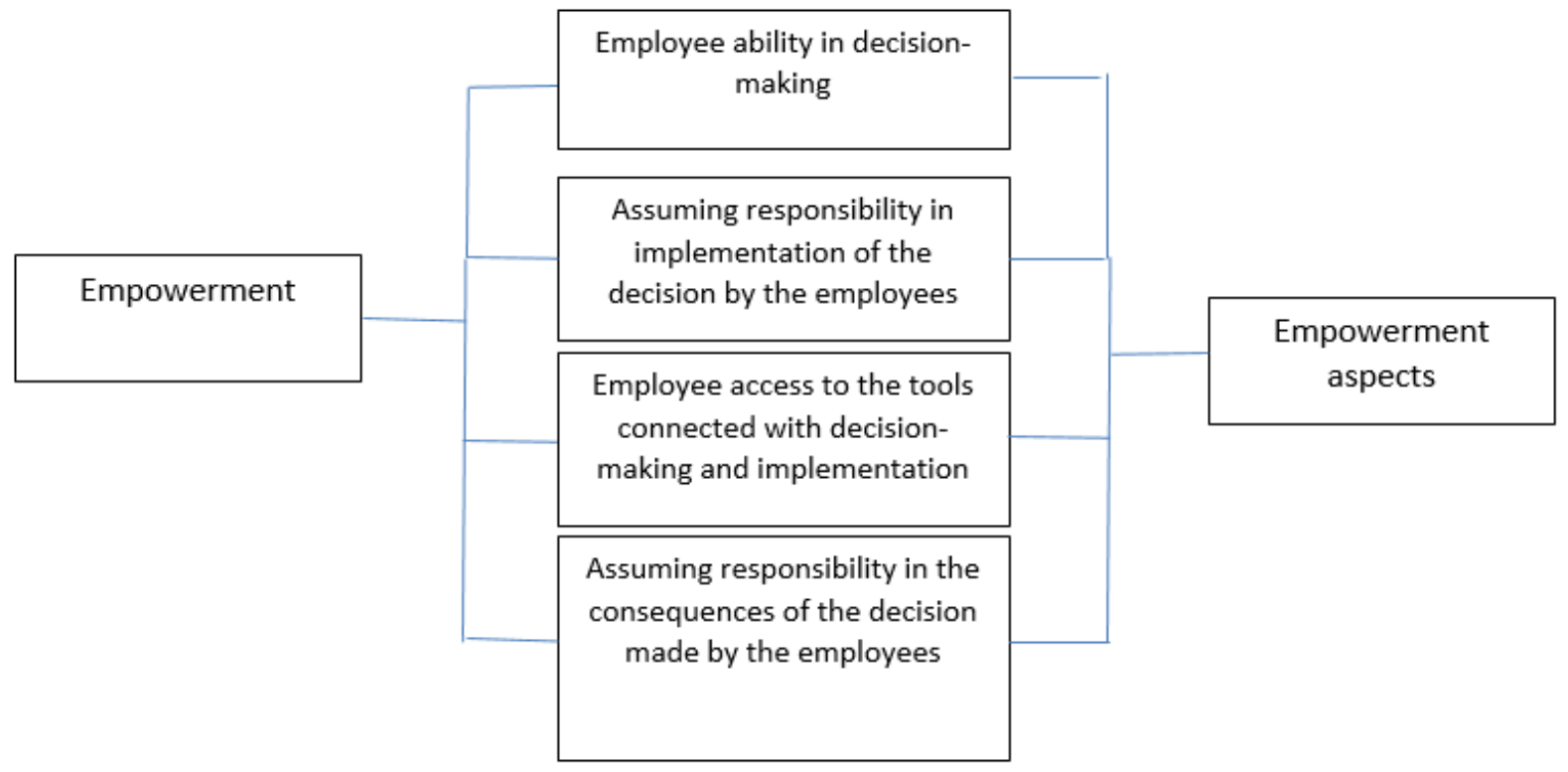

Figure 15- Noller Employee Empowerment Model

Thomas \& Velthouse Employee Empowerment Model (1990)

(Thomas \& Volhaus, 2017) developed and extended the general approach proposed by (Kanger \& Kanengo, 1988) suggesting that empowerment should be considered as a multidimensional construct. In their four-aspect model of employee empowerment, these two scholars had analyzed impact, choice, competence and meaningfulness. They considered impact as making a whole change in the job by performing a specific task. Choice means determining one's own individual behavior and competence is having skill, experience and abilities needed to move forward and finally, meaningfulness is directly related to the adaptation of the value system of the individual and business. Moreover, according to these two scholars, the greater the degree of belief in the impact of work, the opportunity to choose, the needed competence and the degree of meaningfulness, the greater the sense of empowerment of employees will be. Without feeling meaningful, empowerment will not exist per se. They argued that empowerment shows each employee's awareness of self. They also argued that empowerment is not only about evaluating employees' tasks, but also about contextual factors like the interactions of employees with their supervisors, friends and subordinates (Figure 16). 


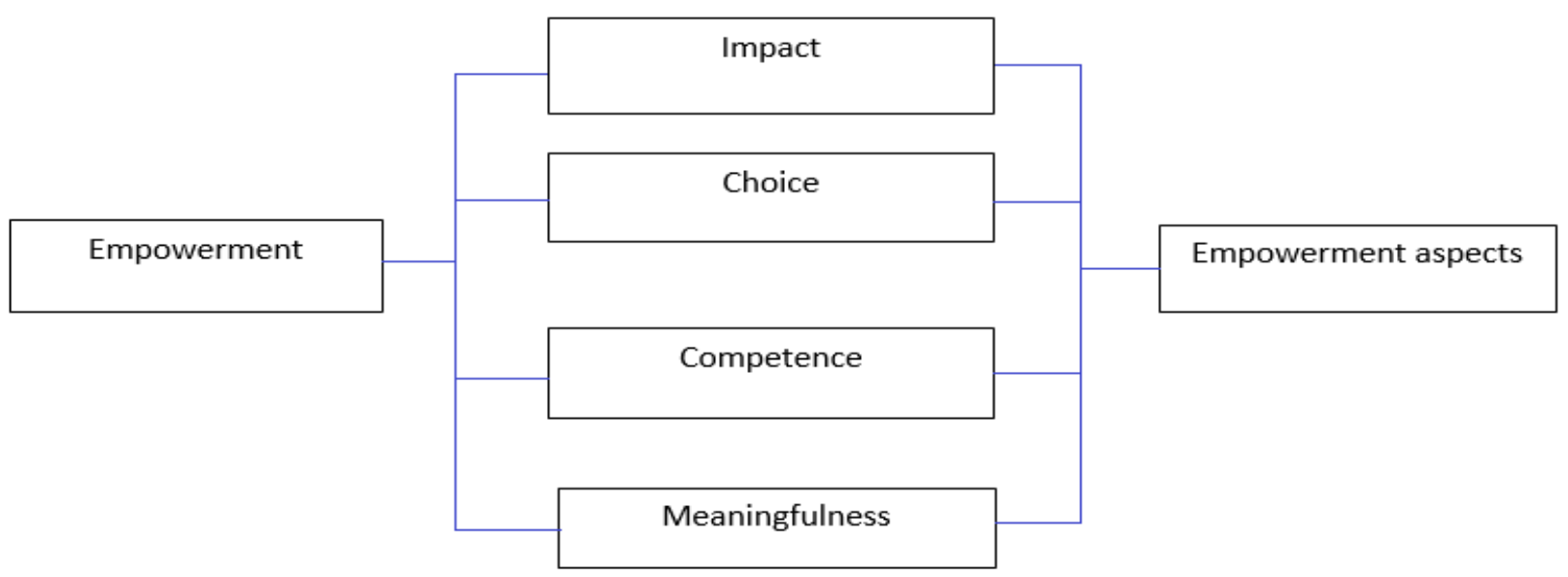

Figure 16- Thomas \& Velthouse`s Employee Empowerment Model

(Spritzer, 1995) presented a new model of empowerment where the role of individuals in explaining and implementing the model was much more emphasized. The four steps in implementing this model were in line with the nine empowerment principles and the seven steps as outlined in the following diagram. (Spritzer, 1995) argued that pre-evaluation observation and debate can ensure that the model is more in line with sociocultural needs and that a clear definition of empowerment is required to present a common understanding of the issue among members (Figure 17). 


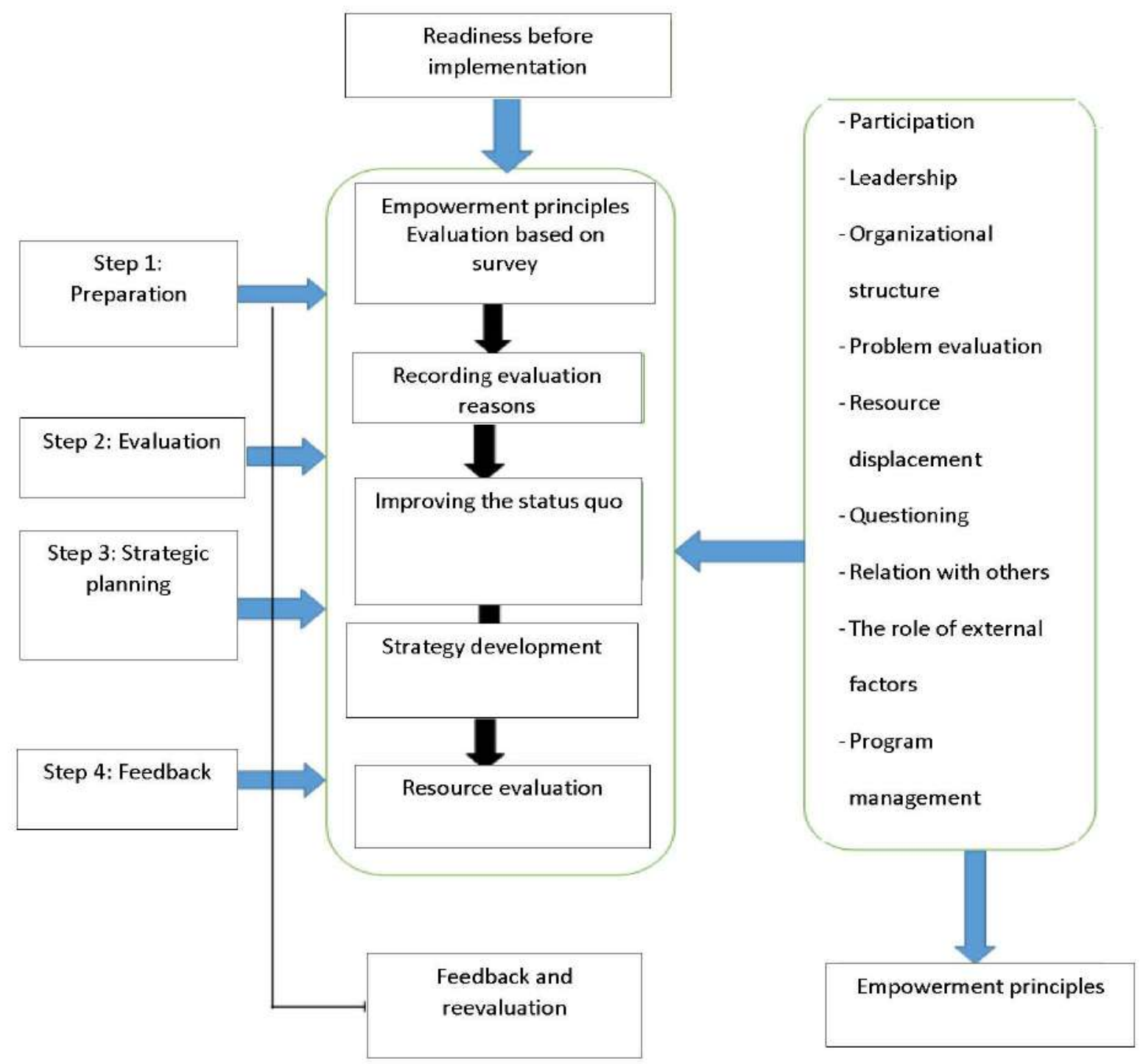

Figure 17. G Laverack`s Employee Empowerment Model

\section{Spritzer Employee Empowerment Model (1995)}

According to (Spritzer, 1995), contrary to the increase in the tendency of scientific management resources to empower, the lack of psychological empowerment in a work environment prevents more studies in the workplace. According to him, empowerment is a continuous variable thus the employees may experience varying degrees of it. With a focus on the psychological approach, Spritzer tried to develop a systematic workplace empowerment network. His model is composed of four components that evaluate the employees' perceptions of meaningfulness, competence, impact, and autonomy. This feeling comes up when the tasks of the job are in line with one's values, beliefs, and behaviors. Feeling competent is the belief in one's 
ability to perform essential activities. Autonomy is an individual's perception of the right to choose what to do. Impact is an individual's perception of the extent to which he is affected by the consequences of a given task (Figure 18).

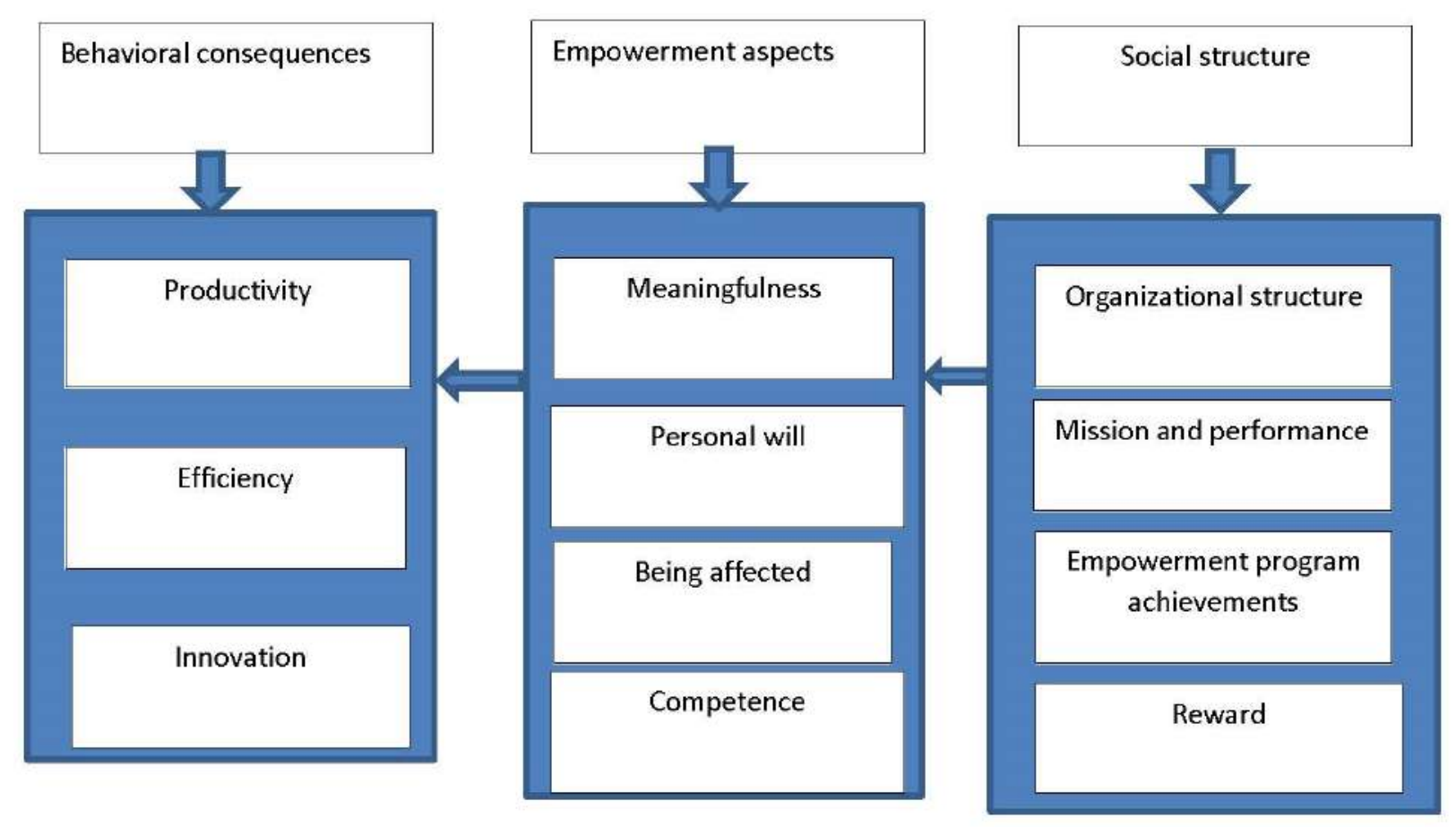

Figure 18- Spritzer Employee Empowerment Model

Employee Empowerment Model of Calbert \& McDonough (1986)

Calbert \& McDonough Employee Empowerment Model is presented in (Figure 19). 


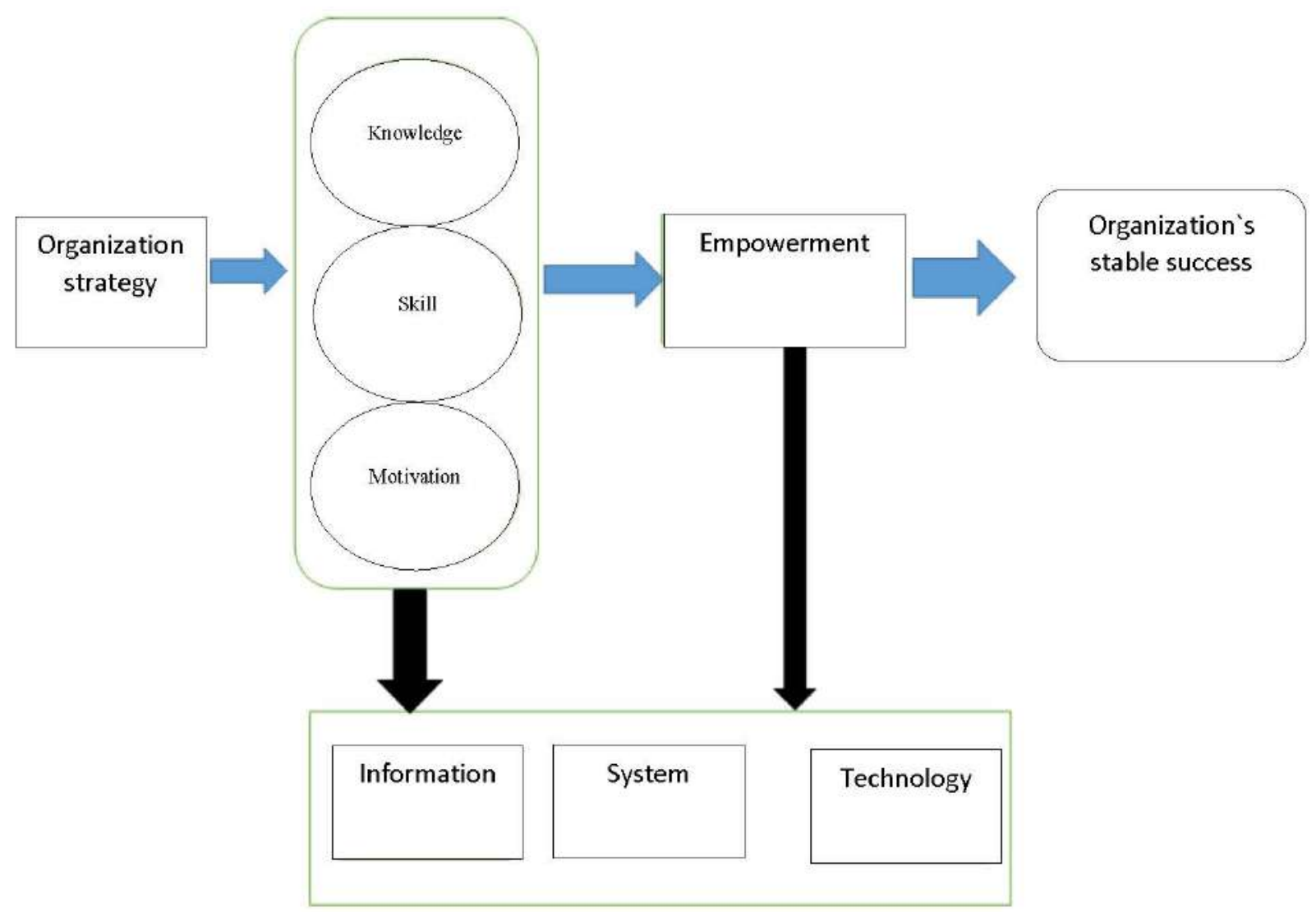

Figure 19- Employee Empowerment Model

Iran Human Resources Empowerment Model

Iran Human Resources Empowerment Model is presented in (Figure 20). 


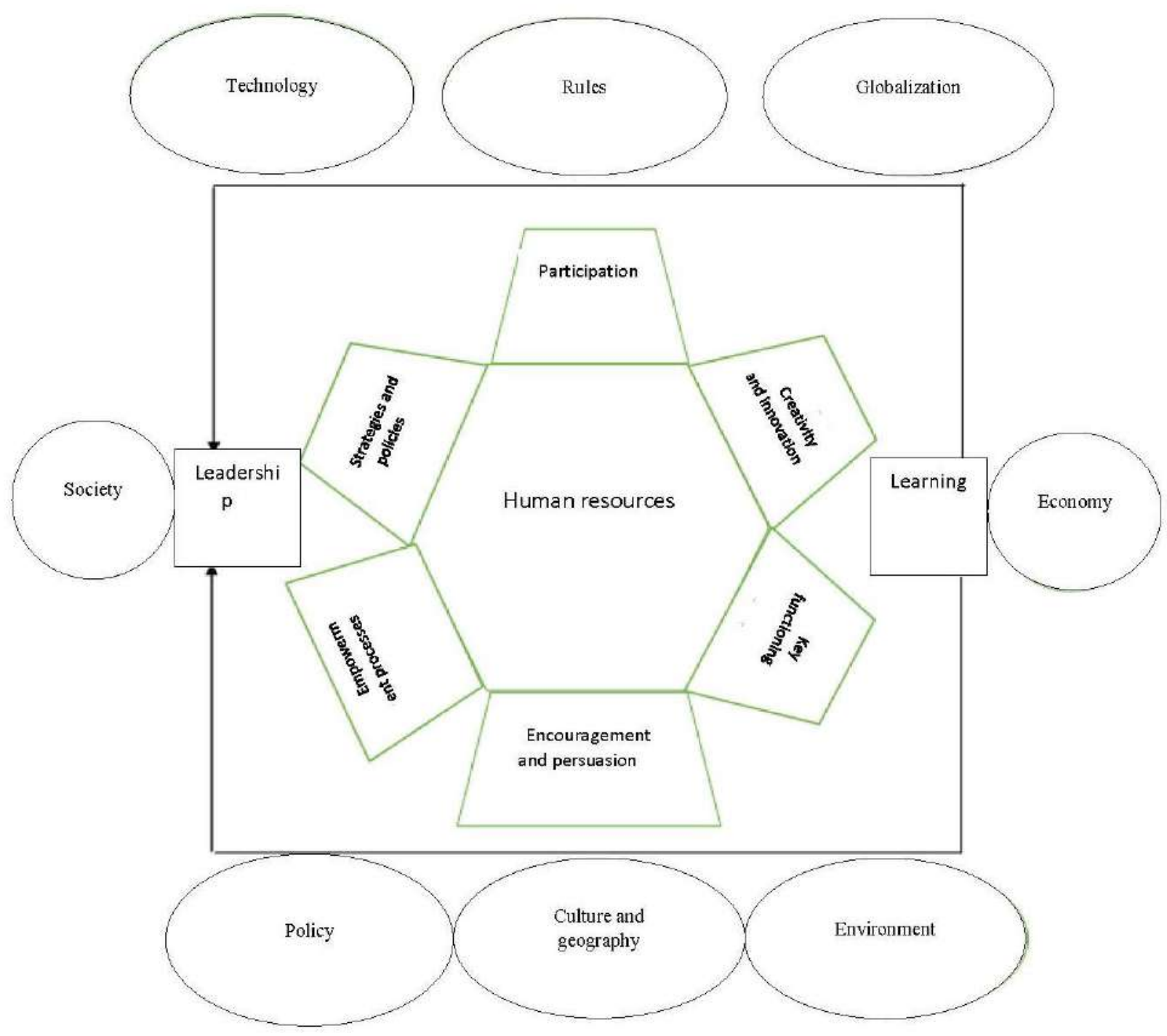

Figure 20- Iran Human Resources Empowerment Model

\section{Employee Empowerment and Occupational Competence Model}

Employee empowerment and occupational competence model is presented in (Figure 21).

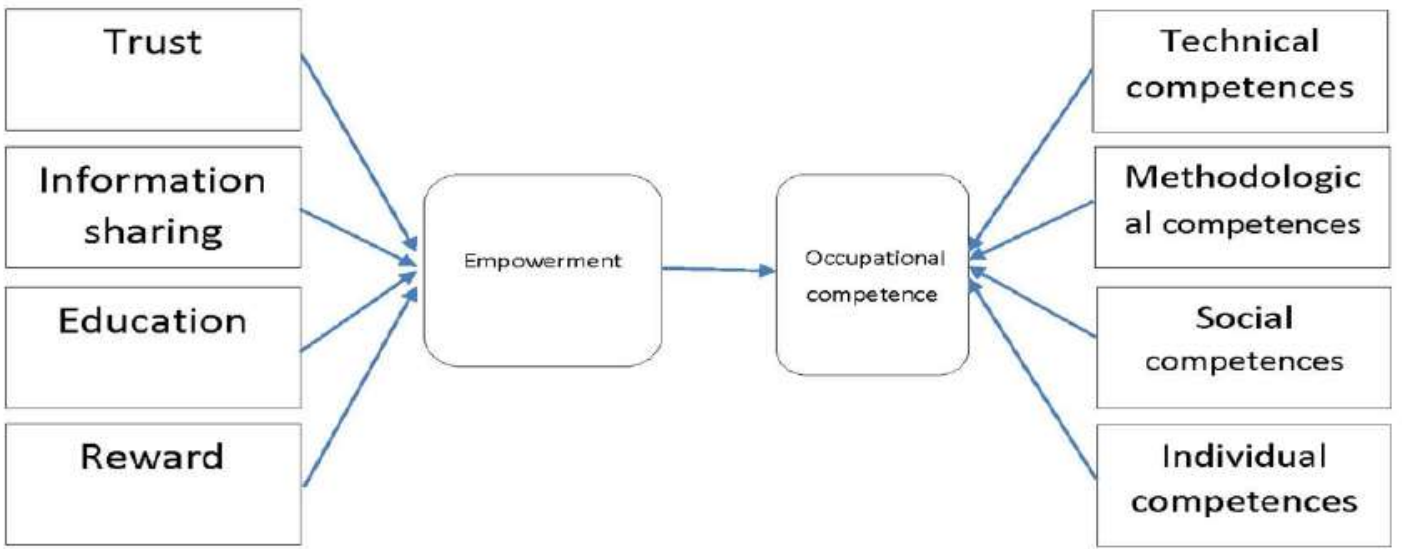

Figure 21- Employee Employment and Occupational Competence Model 


\section{Employee Empowerment Model for Governance Contract Companies}

The employee empowerment model of governance contract companies is presented in (Figure 22).

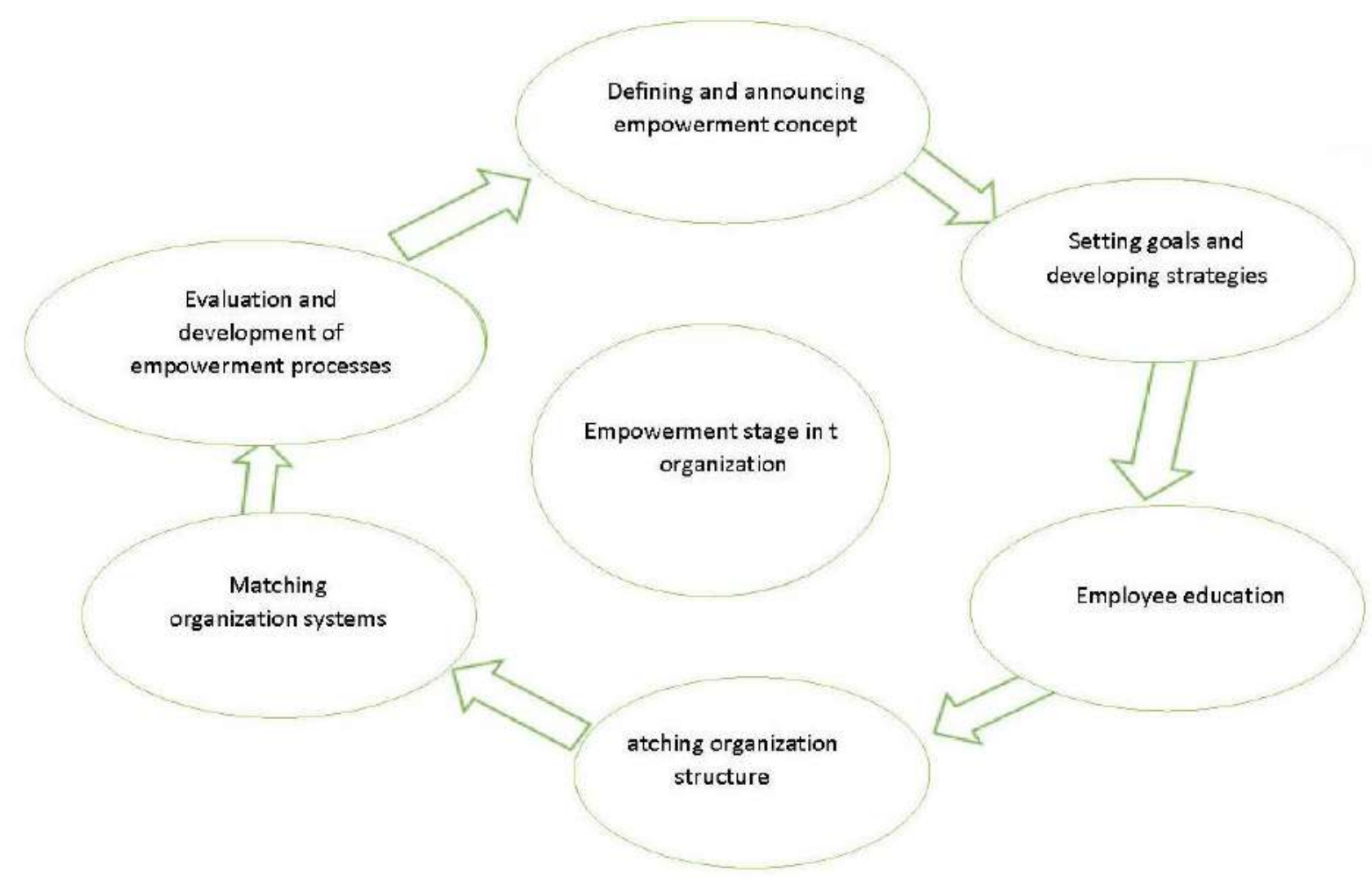

Figure 22- Employee Empowerment Model of Governance Contract Companies

Auto parts industry employee empowerment model

Auto parts industry employee empowerment model is presented in (Figure 23).

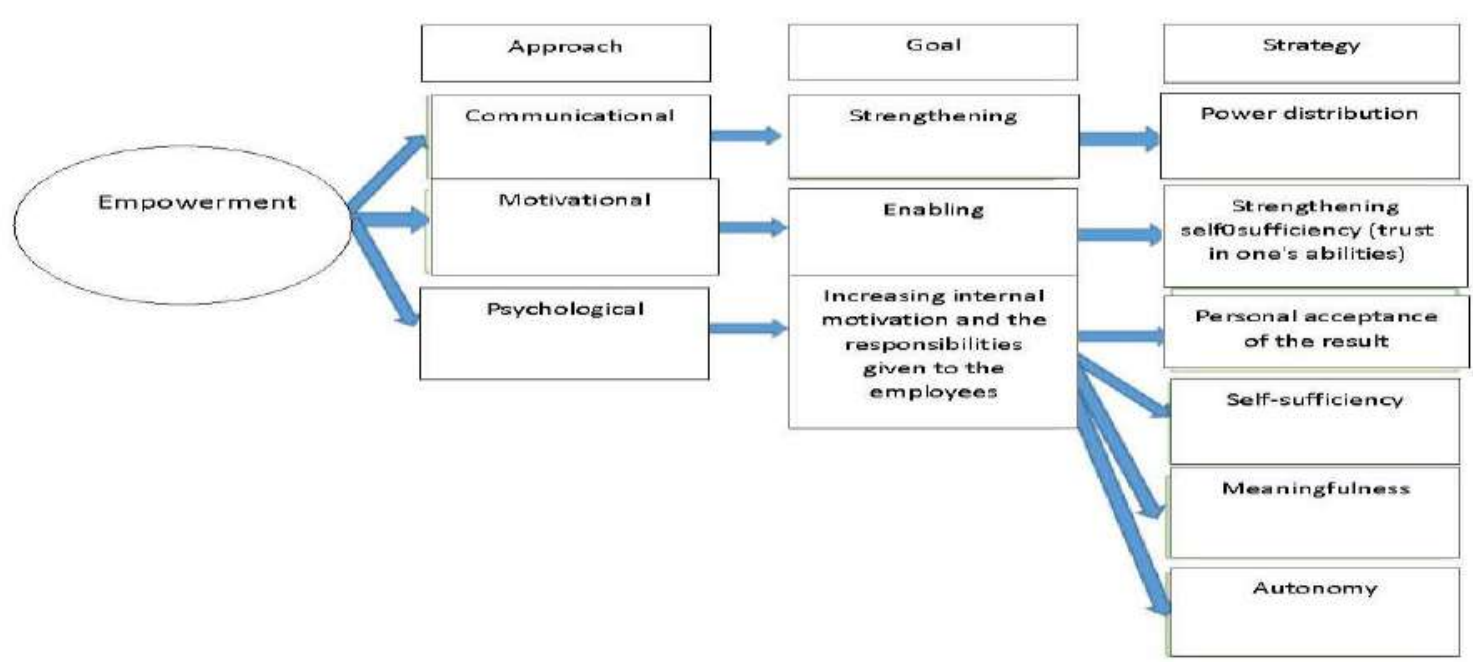

Figure 23- Employees empowerment model of auto parts industry 
National Iranian Oil Products Distribution Company Employee Empowerment Model

The employee empowerment model of auto parts industry is presented in (Figure 24).

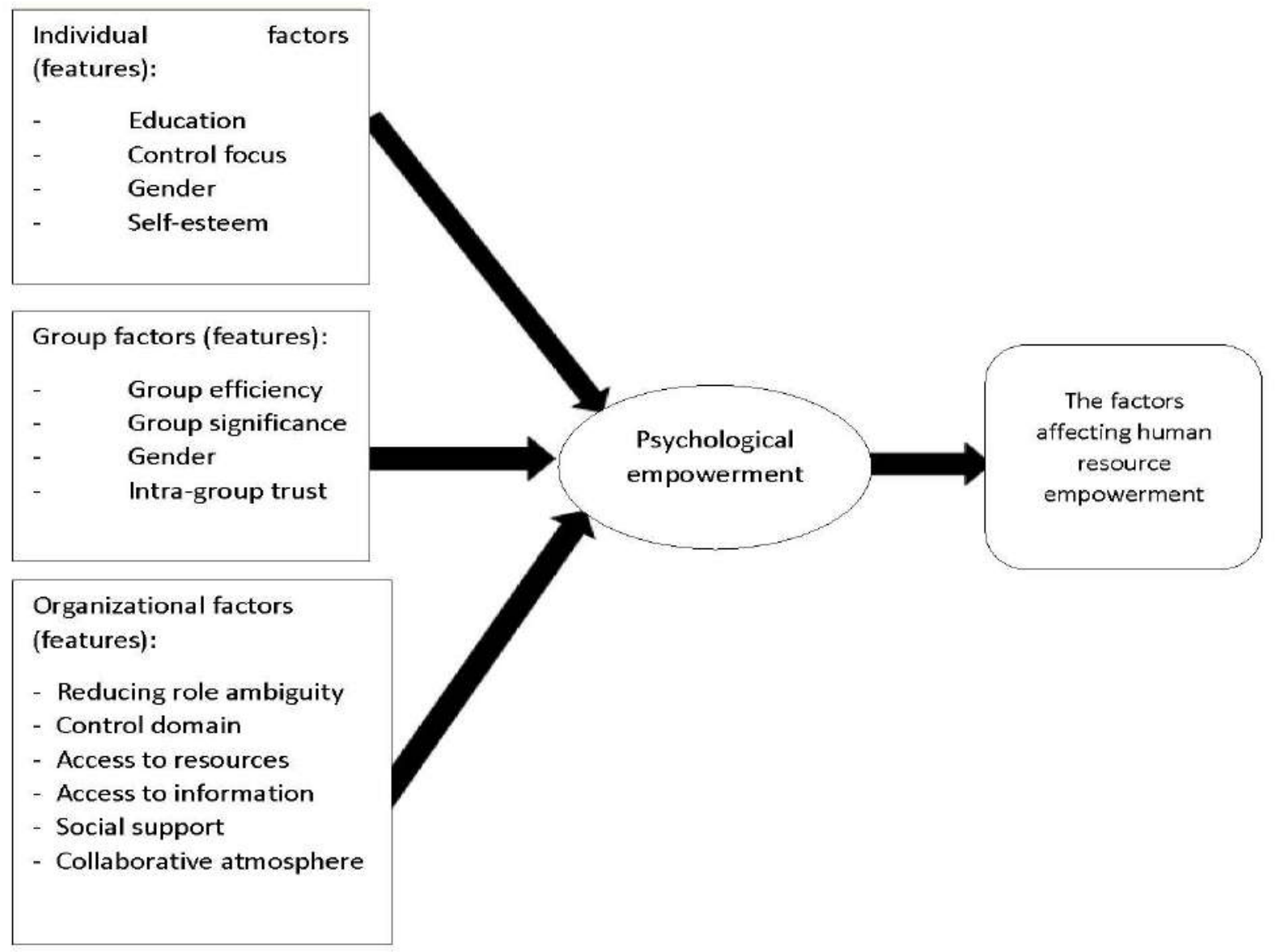

Figure 24- National Iranian Oil Products Distribution Company Employee Empowerment Model

\section{CONCLUSION}

In the competitive world today, human is one of the most significant tools in creating change, survival of the organization, and reaching its goals. Here, what guarantees the change and the survival of the organization is human resources. Empowered human force is one of the major indices of an organization's superiority over others. The fact is that if an organization lacks creative, knowledgeable, opportunistic, and affairs analyst employees, it will lose many opportunities and cases. Empowerment of human forces is so significant given its significant role in the development of society in many aspects. Hence, the organizations have to identify appropriate mechanisms to empower their employees and to mobilize all their capabilities according to their own conditions. 
The first step in empowering employees is to understand the impacts of the empowerment process and the factors affecting it. Given the significance of empowerment, it is imperative that organizations try to enhance their effectiveness by recognizing the factors affecting empowerment and modifying the conditions. Empowerment should be set as the most significant issue of Islamic Azad University as employees' psychological empowerment brings about flexibility in internal organizational changes and is an important element in an organic or systematic organization. Empowering employees is the central focus of managers' efforts to innovate, decentralize, and eliminate bureaucracy in organizations. Empowering individuals will help managers and organizations reach their goals faster and without wasting resources. Empowerment enables the employees to value the organization and the job and be proud of working in it. Neither managers nor organizations can succeed in the long run without empowerment. Organization manager is the most significant element in employee empowerment as the manager directly and indirectly affects all factors of the organizational environment. By delegating more power and authority to the employees, giving them the independence and freedom to act, bringing about a collaborative atmosphere, creating a team-working culture and eliminating the conditions that disable the employees, the manager creates the required context for empowerment. Moreover, reducing occupational stress and increasing job satisfaction are the two of the attitudinal consequences following employees' psychological empowerment in the workplace.

According to this, after analyzing employee empowerment or human resources 'models, the effective model of employee psychological empowerment was extracted in the present study, which involves organizational culture, organizational structure, organizational monitoring system, organizational reward system and organizational management systems. Based on the analyses, and examining and comparing the models developed in this regard, some aspects were considered for each aspect as presented in (Figure 25). 


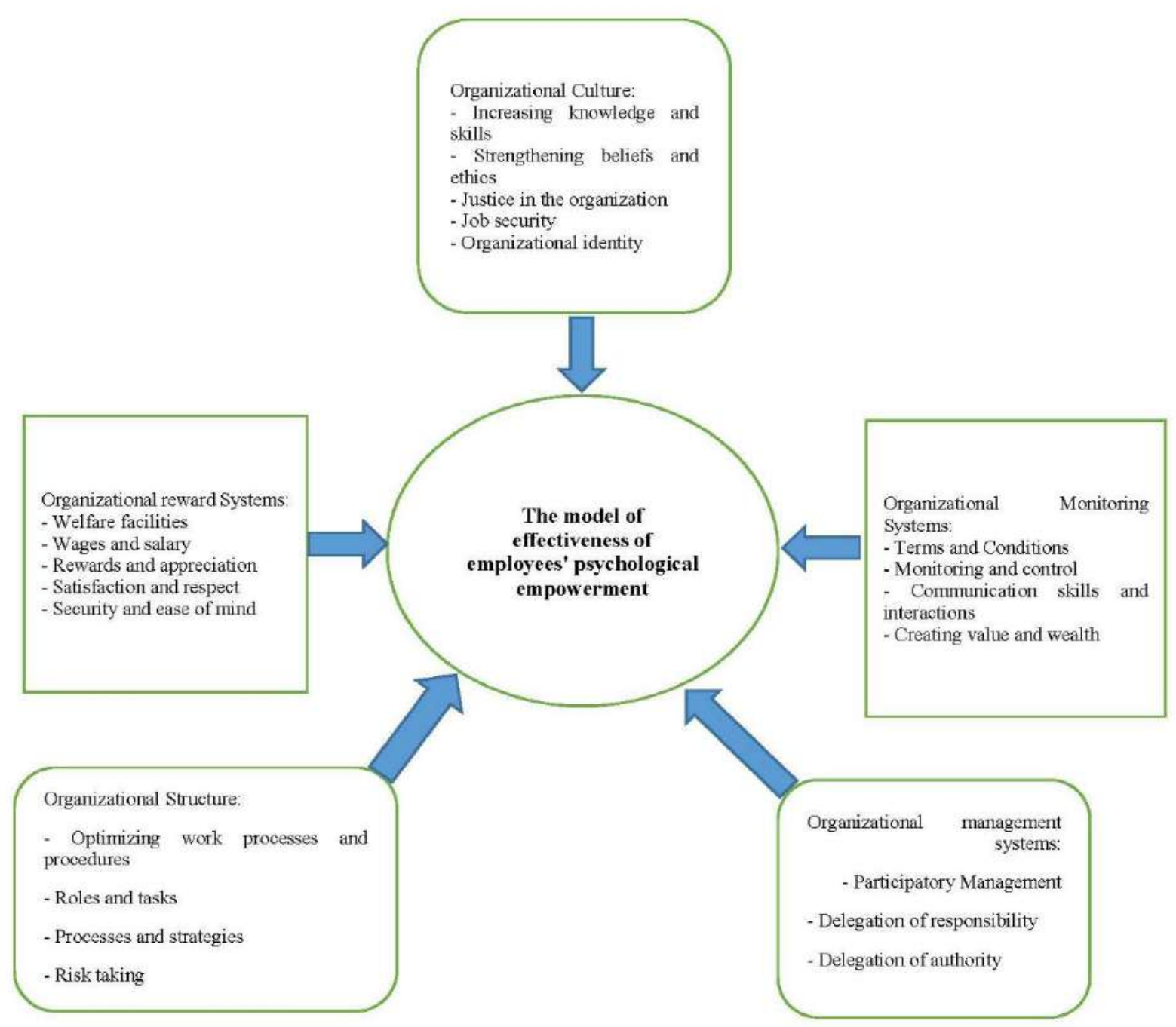

Figure 25: The model presented in the study

\section{REFERENCES}

Bowen S. \& Lawler M. (1992) Investigation of the role of empowerment methods on enhancing human resources performance of Golestan province Payam Noor universities. MS, Birjand University, 6(2): 189-206.

Kanger A. \& Kanengo S. (1988) Empowerment Model for Empowering Employees of Automotive Parts Industry, Iranian Management Science Quarterly, 14(3): 149-169.

Avolio G. (2004) Identification and Explanation of Employee Empowerment Model in Iranian Governmental Organizations (Case Study of Yazd Province), Management Research, Second Year, Third Issue, 15(6): 75-94.

Nokelainen K. \& Ruhotie J. (2003) The Relationship between Organizational Spirituality with Psychological Empowerment, Creativity, Spiritual Intelligence, Job Stress and Job Satisfaction of University Personnel, Journal of Behavioral Sciences, 6(2): 54-69.

Dennis K. (1984) Employee Empowerment General, Tehran, Behamouz Publications, 6(3): 177-189. Robbins F. \& Crino M. \& Fredendal H. (2018). The Impact of Electronic Readiness on Job Empowerment of Government Employees (Case Study: Guilan Provincial Governors and Subsidiaries), New Research in Management and Accounting, 4(11): 65-78. 
Villegas D. (2019) Examination of the Role of Cognitive Empowerment Dimensions on Creators' Creativity Habits. Sport Management Studies, 31(4): 200-229.

Vogt B. \& Murrel G. 1990) Designing and Developing Strategic Model of Human Resources Empowerment in Knowledge-Based Organizations, Journal of Human Resource Management Research, 1(3): 23-54.

Noller R. (1997) Effective Factors on Empowering Personnel of Management and Planning Organization. Tehran: Third Conference on Human Resources Development, 8(4): 74-85.

Spritzer L. (1995), Identification and Modeling of Factors Affecting Empowerment of Maritime Managers, Journal of Marine Science Education, 4(8): 14-29.

Shahabi S. \& Emaminejad M. (2017) The Relationship of Professional Ethics with Psychological Empowerment of University Staff, Annual Conference on New Management Paradigms in the Field of Intelligence, Tehran, Permanent Secretariat of Conference, University of Tehran, 8(2): 258-266. Baghersalimi E. \& Dashmir W. (2018) Human Resources Empowerment, Tehran: Avaye Noor Publications, 9(1): 22-32.

Samadi Mirklaei H. \& Aghajani H. \& Samadi Mirklaei H. (2013) Examination of the Relationship between Transformational Leadership and Psychological Empowerment of Employees (Experimental Control: Babolsar Education Department), Journal of Educational Leadership and Management in Garmsar University, 1(7): 117-138.

Lotfi Zanganeh D. \& Oboudi H. \& Kazemian F. (2014) The Relationship between Organizational Culture and Empowerment of Employees, Two Quarterly Journal of Human Resource Management Research, Imam Hossein University, 6(1): 47-62.

Ghiasi Nadoushan S. \& Jahani Jarmandehari F. \& Khorsandi Taskouh A. (2016) Examination of the Relationship between Psychological Empowerment and Creativity among Staff of the Ministry of Communication and Information Technology. Journal of Innovation and Creativity in the Humanities, Sixth Year, 18(3): 77-96.

Ghorbanizadeh V. \& Aghavardi B. (2013) Examination of the Role of Employees' Psychological Empowerment in Organizational Excellence in Iranian Customs, Journal of Human Resource Management Research, 5(1): 87-106.

Kordnaij A. \& Bakhshizadeh A. Fath Elahi M. (2015) Examination of the Impact of Employees' Psychological Empowerment on Structural Empowerment (Case Study: Saipa Company). Journal of Organizational Behavior Studies, Fourth Year, 6(11): 97- 120.

Babolan Z. (2017) Examination of Factors Affecting Human Resources Empowerment of National Iranian Oil Products Distribution Company, Quarterly Journal of Development and Transformation Management, Sixth Year, 5(4): 49-56.

Jazani N. \& Rostami T. (2011) Designing a Human Resources Empowerment Model in the National Media. Journal of Communication Research, Nineteenth Year, 72(3): 93-114.

Firouzfar F. \& Zam F. \& Mansouri A. \& Vali Zibae Kh. (2017), An Introduction to the Conceptual Literature of Social Psychological Empowerment, Journal of Emerging Psychology, 6(2): 189-206.

Mirmohammadi L. \& Khorakian A. \& Nazemi Sh. (2017) Examination of the impact of psychological empowerment on employees' innovative behavior with regard to their career aspirations. Quarterly Journal of Management Development, 25(13): 17-26 


\section{Ahad Shahbazian}

PhD student of Human Resource Management, Management Department, Rafsanjan Branch, Islamic Azad University, Rafsanjan, Iran. E-mail: Sh iau@yahoo.com

ORCID: https://orcid.org/0000-0002-8010-7056

\section{Malikeh Beheshtifar}

Associate Professor, Management Department, Rafsanjan Branch, Islamic Azad University, Rafsanjan, Iran. E-mail: $\underline{m}$.beheshtifar@iaurafsanjan.ac.ir

ORCID: https://orcid.org/0000-0002-2157-288X

Received on: 01-03-2020

Approved on: 02-20-2020

Published on: 03-19-2020 